\title{
Total Synthesis and Cytotoxicity Studies of a Cyclic Depsipeptide with Proposed Structure of Palau'amide
}

\author{
Bin Zou, Kai Long and Dawei Ma* \\ State Key Laboratory of Bioorganic and Natural Products Chemistry, Shanghai Institute of Organic Chemistry, Chinese Academy of Sciences, \\ 354 Fenglin Lu, Shanghai 200032, China \\ Madw@mail.sioc.ac.cn
}

\section{Supporting Information}

Table of contents

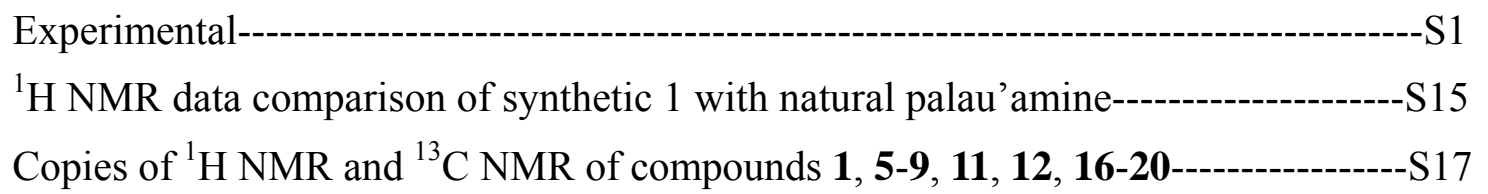




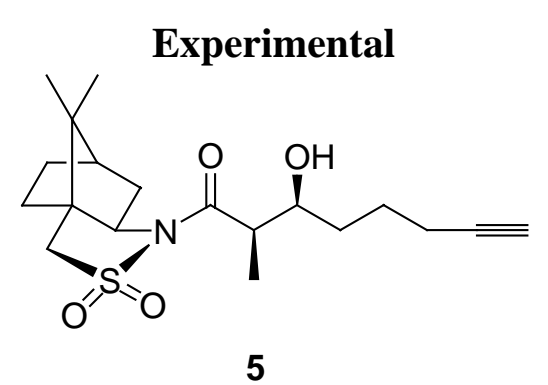

Aldol reaction of $N$-propionylsultam 4 with 5-hexynal. $\mathrm{CF}_{3} \mathrm{SO}_{3} \mathrm{H}(1.8 \mathrm{~mL}, 20 \mathrm{mmol})$ was added to $\mathrm{Et}_{3} \mathrm{~B}$ (1.0 $\mathrm{M}$ solution in hexane, 20 $\mathrm{mL}, 20 \mathrm{mmol}$ ) slowly at room temperature under nitrogen. The resultant solution was heated at $40{ }^{\circ} \mathrm{C}$ and stirred until gas evolution had ceased. Successive addition of a solution of $\mathrm{N}$-propionylsultam $4(2.8 \mathrm{~g}, 10 \mathrm{mmol})$ in $\mathrm{CH}_{2} \mathrm{Cl}_{2}(10 \mathrm{~mL})$ and DIPEA $(3.6 \mathrm{~mL}, 15.9 \mathrm{mmol})$ at $-15^{\circ} \mathrm{C}$ and stirring was continued for $30 \mathrm{~min}$. The resulting boryl enolate solution was cooled to $-78{ }^{\circ} \mathrm{C}$. To the solution was cannulated a precooled $\left(-78^{\circ} \mathrm{C}\right)$ solution of 5-hexynal $(2.0 \mathrm{~g}, 21 \mathrm{mmol})$ in $\mathrm{CH}_{2} \mathrm{Cl}_{2}(10 \mathrm{~mL})$. The resulting mixture was stirred for $2 \mathrm{~h}$ and quenched with saturated $\mathrm{NH}_{4} \mathrm{Cl}$. The water layer was extracted with $\mathrm{CH}_{2} \mathrm{Cl}_{2}$ for three times. The combined organic layers were dried over $\mathrm{Na}_{2} \mathrm{SO}_{4}$ and concentrated in vacuo. The residue was purified by chromatography eluting with $1: 4$ ethyl acetate/petroleum ether to give $3.5 \mathrm{~g}$ of 5 as colorless oil in $90 \%$ yield. $[\alpha]_{\mathrm{D}}{ }^{20}=$ -86.7 (c 0.9, $\mathrm{CHCl}_{3}$ ); IR (film) 3529, 3290, 2116, 1687, $1458 \mathrm{~cm}^{-1} ;{ }^{1} \mathrm{H} \mathrm{NMR}\left(300 \mathrm{MHz}, \mathrm{CDCl}_{3}\right) \delta 4.03(\mathrm{~m}, 1 \mathrm{H}), 3.93(\mathrm{t}, J=6.3 \mathrm{~Hz}, 1 \mathrm{H}), 3.52(\mathrm{q}$, $J=11.4 \mathrm{~Hz}, 2 \mathrm{H}), 3.15(\mathrm{~m}, 2 \mathrm{H}), 2.26(\mathrm{~m}, 2 \mathrm{H}), 2.09(\mathrm{~m}, 2 \mathrm{H}), 1.90(\mathrm{~m}, 4 \mathrm{H}), 1.80(\mathrm{~m}, 1 \mathrm{H}), 1.62-1.39(\mathrm{~m}, 5 \mathrm{H}), 1.30(\mathrm{~d}, J=6.6 \mathrm{~Hz}, 3 \mathrm{H}), 1.19(\mathrm{~s}, 3 \mathrm{H})$, $1.02(\mathrm{~s}, 3 \mathrm{H}) ;{ }^{13} \mathrm{C} \mathrm{NMR}\left(75 \mathrm{MHz}, \mathrm{CDCl}_{3}\right) \delta 176.85,84.10,70.03,68.44,64.75,52.89,48.23,47.59,44.45,43.89,38.13,32.73,32.66,26.26$, 24.78, 20.63, 19.69, 18.12, 11.36; ESIMS m/z $368(\mathrm{M}+\mathrm{H})^{+}$; HRMS Calcd. for $\mathrm{C}_{19} \mathrm{H}_{29} \mathrm{NO}_{4} \mathrm{Na}(\mathrm{M}+\mathrm{Na})^{+}$requires 390.1710 , found 370.1713 . 


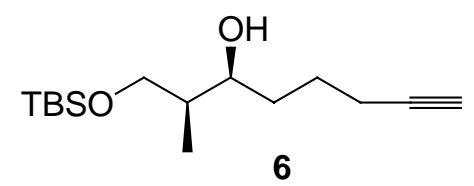

(2S,3S)-1-tert-Butyldimethylsiloxyl-2-methyl-3-hydroxy-7-octyne 6. A solution of 5 (1.7 g, $4.6 \mathrm{mmol})$ in dry THF (5 mL) was added to a boiling THF $(30 \mathrm{~mL})$ suspension of $\mathrm{LiAlH}_{4}(234 \mathrm{mg}, 6.9 \mathrm{mmol})$ under nitrogen. After refluxing for $1 \mathrm{~h}$, the reaction mixture was cooled to room temperature and quenched by sequentially adding $0.25 \mathrm{~mL}$ of water, $0.25 \mathrm{~mL}$ of $15 \%$ aqueous $\mathrm{NaOH}$ and $0.25 \mathrm{~mL}$ of water slowly. The white solid was filtered and the filtrate was concentrated. The residue was purified by chromatography eluting with 1:1 ethyl acetate/petroleum ether to give $640 \mathrm{mg}$ of diol as a colorless oil.

To a solution of above product $(0.8 \mathrm{~g}, 5.1 \mathrm{mmol})$ in DMF $(3 \mathrm{~mL})$ were added imidazole $(385 \mathrm{mg}, 5.6 \mathrm{mmol})$ and tert-butyldimethylsilyl chloride $(773 \mathrm{mg}, 5.1 \mathrm{mmol})$ under nitrogen. The resulting solution was stirred overnight and diluted with ethyl acetate. After washed with brine three times, the organic layer was dried over $\mathrm{Na}_{2} \mathrm{SO}_{4}$ and concentrated in vacuo. The residue was purified by chromatography eluting with $1: 5$ ethyl acetate/petroleum ether to give $1.38 \mathrm{~g}$ of $\mathbf{6}$ as colorless oil in $88 \%$ yield for 2 steps. $\quad[\alpha]_{\mathrm{D}}{ }^{20}=-8.7\left(c 1.2, \mathrm{CHCl}_{3}\right)$; IR (film) 3462,3315 , 2119, 1472, $1464 \mathrm{~cm}^{-1} ;{ }^{1} \mathrm{H}$ NMR (300 MHz, $\left.\mathrm{CDCl}_{3}\right) \delta 3.80(\mathrm{~m}, 2 \mathrm{H}), 3.70(\mathrm{~m}, 1 \mathrm{H}), 3.20(\mathrm{~d}, J=2.4 \mathrm{~Hz}, 1 \mathrm{H}), 2.26(\mathrm{~m}, 2 \mathrm{H}), 1.96(\mathrm{t}, J=2.7 \mathrm{~Hz}$, $1 \mathrm{H}), 1.77(\mathrm{~m}, 2 \mathrm{H}), 1.62-1.52(\mathrm{~m}, 3 \mathrm{H}), 0.93(\mathrm{~d}, J=7.5 \mathrm{~Hz}, 3 \mathrm{H}), 0.91(\mathrm{~s}, 9 \mathrm{H}), 0.10(\mathrm{~s}, 6 \mathrm{H}) ;{ }^{13} \mathrm{C} \mathrm{NMR}\left(75 \mathrm{MHz}, \mathrm{CDCl}_{3}\right) \delta 84.35,74.06,68.30$, 68.10, 38.98, 32.98, 25.76, 25.13, 18.33, 18.05, 10.28, -5.67, -5.73; ESIMS $m / z 271(\mathrm{M}+\mathrm{H})^{+}$; HRMS Calcd. for $\mathrm{C}_{15} \mathrm{H}_{30} \mathrm{O}_{2} \mathrm{SiNa}(\mathrm{M}+\mathrm{Na})^{+}$ requires 293.1907, found 293.1913. 


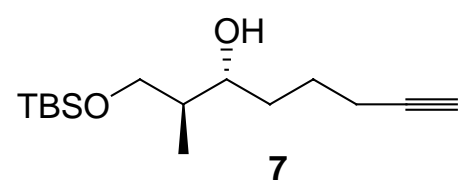

(2S,3R)-1-tert-Butyldimethylsiloxyl-2-methyl-3-hydroxy-7-octyne 7. To a solution of $6(1.3 \mathrm{~g}, 4.8 \mathrm{mmol})$ in benzene $(80 \mathrm{~mL})$ were sequentially added $\mathrm{Ph}_{3} \mathrm{P}(8.83 \mathrm{~g}, 33.7 \mathrm{mmol})$, p-nitrobenzoic acid $(5.64 \mathrm{~g}, 33.7 \mathrm{mmol})$ and DEAD (5.3 mL, $\left.33.7 \mathrm{mmol}\right)$ under nitrogen. The resulting mixture was stirred for 3 days and quenched with saturated $\mathrm{NaHCO}_{3}$. The water layer was extracted with ethyl acetate. The combined organic layers were dried over $\mathrm{Na}_{2} \mathrm{SO}_{4}$ and concentrated in vacuo. The residue was purified by chromatography eluting with 1:20 ethyl acetate/petroleum ether to give $2.1 \mathrm{~g}$ of ester, which was dissolved in $23 \mathrm{~mL}$ of methanol before $\mathrm{NaOH}(0.96 \mathrm{~g}, 24 \mathrm{mmol})$ was added. The resultant solution was stirred for $2 \mathrm{~h}$, and then concentrated. The residue was diluted with ethyl acetate and washed with brine. The organic layer was dried over $\mathrm{Na}_{2} \mathrm{SO}_{4}$ and concentrated in vacuo. The residue was purified by chromatography eluting with 1:9 ethyl acetate/petroleum ether to give $1.12 \mathrm{~g}$ of 7 as slight yellow oil in $86 \%$ yield. $[\alpha]_{\mathrm{D}}{ }^{20}=+28.1\left(c 0.8, \mathrm{CHCl}_{3}\right)$; IR (film) $3483,3315,2119,1473,1464 \mathrm{~cm}^{-1} ;{ }^{1} \mathrm{H} \mathrm{NMR}$ $\left(300 \mathrm{MHz}, \mathrm{CDCl}_{3}\right) \delta 3.96(\mathrm{~d}, J=3.3 \mathrm{~Hz}, 1 \mathrm{H}), 3.82(\mathrm{dd}, J=4.5,10.2 \mathrm{~Hz}, 1 \mathrm{H}), 3.56(\mathrm{~m}, 2 \mathrm{H}), 2.25(\mathrm{~m}, 2 \mathrm{H}), 1.95(\mathrm{t}, J=2.7 \mathrm{~Hz}, 1 \mathrm{H}), 1.82-1.48(\mathrm{~m}$, 5H), $0.91(\mathrm{~s}, 9 \mathrm{H}), 0.86(\mathrm{~d}, J=6.6 \mathrm{~Hz}, 3 \mathrm{H}), 0.10(\mathrm{~s}, 6 \mathrm{H}) ;{ }^{13} \mathrm{C} \mathrm{NMR}\left(75 \mathrm{MHz}, \mathrm{CDCl}_{3}\right) \delta$ 84.45, 75.98, 68.34, 68.21, 39.52, 33.96, 25.75, 24.12, 18.35, 18.02, 13.45, -5.69, -5.76; ESIMS m/z, $271(\mathrm{M}+\mathrm{H})^{+}$; HRMS Calcd. for $\mathrm{C}_{15} \mathrm{H}_{31} \mathrm{O}_{2} \mathrm{Si}(\mathrm{M}+\mathrm{H})^{+}$requires 271.2088, found 271.2086.

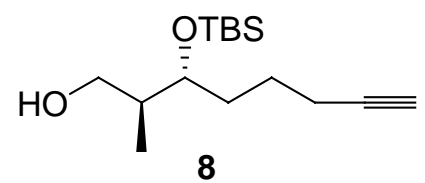


(2S,3R)-1-Hydroxy-2-methyl-3-tert-butyldimethylsiloxyl-7-octyne 8. To a solution of 7 (1.0 g, $3.71 \mathrm{mmol})$ in DMF (5 mL) was added imidazole $(0.75 \mathrm{~g}, 11.1 \mathrm{mmol})$ and tert-butyldimethylsilyl chloride $(1.11 \mathrm{~g}, 7.4 \mathrm{mmol})$ under nitrogen. The resulting solution was stirred overnight and diluted with ethyl acetate. After washed with brine three times, the organic layer was dried over $\mathrm{Na}_{2} \mathrm{SO}_{4}$ and concentrated in vacuo. The residue was purified by chromatography eluting with 1:25 ethyl acetate/petroleum ether to give $1.42 \mathrm{~g}$ of product.

To a solution of the above product $(1.05 \mathrm{~g}, 2.7 \mathrm{mmol})$ in pyridine $(9 \mathrm{~mL})$ and THF $(78 \mathrm{~mL})$ was added HF. Pyridine (3.97 g, $13.5 \mathrm{mmol})$. The solution was stirred overnight and quenched with sat. $\mathrm{NaHCO}_{3}$. The organic layer was dried over $\mathrm{Na}_{2} \mathrm{SO}_{4}$ and concentrated in vacuo. The residue was purified by chromatography eluting with $1: 9$ ethyl acetate/petroleum ether to give $0.69 \mathrm{~g}$ of $\mathbf{8}$ in $94 \%$ yield for 2 steps. $[\alpha]_{\mathrm{D}}{ }^{20}=-14.2$ (c 0.8, $\mathrm{CHCl}_{3}$ ); IR (film) 3315, 2120, 1473, $1464 \mathrm{~cm}^{-1} ;{ }^{1} \mathrm{H}$ NMR $\left(300 \mathrm{MHz}, \mathrm{CDCl}_{3}\right) \delta 3.75(\mathrm{~m}, 2 \mathrm{H}), 3.56(\mathrm{~m}, 1 \mathrm{H}), 2.63(\mathrm{~d}, J=5.4 \mathrm{~Hz}, 1 \mathrm{H}), 2.23$ $(\mathrm{m}, 2 \mathrm{H}), 1.98(\mathrm{t}, J=2.7 \mathrm{~Hz}, 1 \mathrm{H}), 1.84-1.54(\mathrm{~m}, 5 \mathrm{H}), 1.01(\mathrm{~d}, J=6.9 \mathrm{~Hz}, 3 \mathrm{H}), 0.93(\mathrm{~s}, 9 \mathrm{H}), 0.12(\mathrm{~s}, 6 \mathrm{H}) ;{ }^{13} \mathrm{C} \mathrm{NMR}(75 \mathrm{MHz}, \mathrm{CDCl})_{3} \delta 84.11$, 76.36, 68.57, 65.41, 38.36, 33.51, 28.85, 23.68, 18.56, 17.96, 14.23, -4.31, -4.77; EI-MS m/z $271(\mathrm{M}+\mathrm{H})^{+}, 255,211,171,75$; HRMS Calcd. for $\mathrm{C}_{15} \mathrm{H}_{31} \mathrm{O}_{2} \mathrm{Si}(\mathrm{M}+\mathrm{H})^{+}$requires 271.2088, found 271.2087.
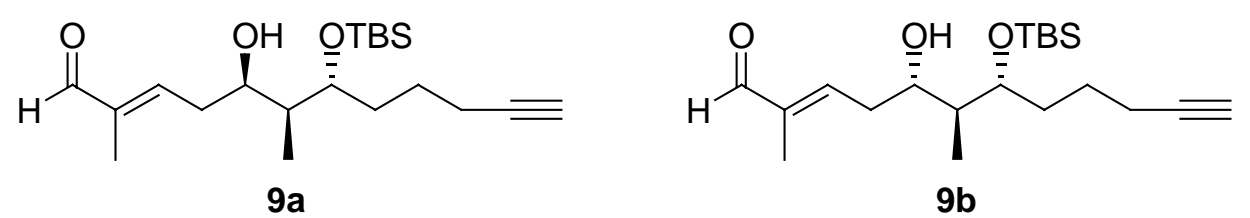

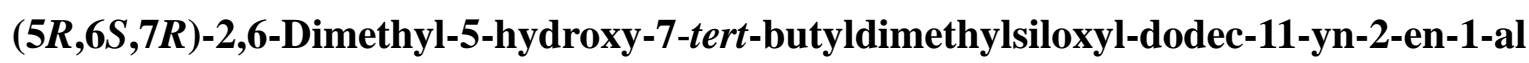


mmol) in $\mathrm{CH}_{2} \mathrm{Cl}_{2}(100 \mathrm{~mL})$ was added DMSO $(2.4 \mathrm{~mL}, 33.8 \mathrm{mmol})$ slowly at $-78{ }^{\circ} \mathrm{C}$ under nitrogen. After stirring was continued for 20 min, a solution of $8(1.7 \mathrm{~g}, 6.3 \mathrm{mmol})$ in $\mathrm{CH}_{2} \mathrm{Cl}_{2}(10 \mathrm{~mL})$ was added slowly. The resultant solution was stirred for $1 \mathrm{~h}$ before triethylamine $(6.8 \mathrm{~mL}$, $48.8 \mathrm{mmol}$ ) was added at $-78{ }^{\circ} \mathrm{C}$. After the mixture was stirred for $2 \mathrm{~h}$, it was warmed to room temperature slowly, and then quenched with saturated $\mathrm{NH}_{4} \mathrm{Cl}$. The water layer was extracted with chloroform. The combined organic layers were dried over $\mathrm{Na}_{2} \mathrm{SO}_{4}$ and concentrated in vасио. The residue was purified by chromatography eluting with 1:15 ethyl acetate/petroleum ether to give $1.36 \mathrm{~g}$ of aldehyde in $80 \%$ yield.

To a solution of the above aldehyde $(0.885 \mathrm{~g}, 3.3 \mathrm{mmol})$ in $\mathrm{CH}_{2} \mathrm{Cl}_{2}(18 \mathrm{~mL})$ and $\mathrm{Et}_{2} \mathrm{O}(2 \mathrm{~mL})$ were sequentially added (E)-trimethyl(2-methylbuta-1,3-dienyloxy)- silane $(0.78 \mathrm{~g}, 5.0 \mathrm{mmol})$ and $\mathrm{Et}_{2} \mathrm{O} \cdot \mathrm{BF}_{3}(0.62 \mathrm{~mL}, 5.0 \mathrm{mmol})$ at $-78{ }^{\circ} \mathrm{C}$ under nitrogen. The stirring was continued for $24 \mathrm{~h}$ at $-78{ }^{\circ} \mathrm{C}$ and then the reaction was quenched with brine. The water layer was extracted with chloroform. The combined organic layers were dried over $\mathrm{Na}_{2} \mathrm{SO}_{4}$ and concentrated in vacuo. The residue was purified by chromatography eluting with 1:20 ethyl acetate/petroleum ether to give $89 \mathrm{mg}$ of substrate aldehyde and then eluting with 1:5 ethyl acetate/petroleum ether to give $755 \mathrm{mg}$ of $9 \mathbf{a}$ and 58 $\operatorname{mg} 9 \mathbf{b}$ in $65 \%$ and $5 \%$ yield, respectively.

9a: $[\alpha]_{\mathrm{D}}{ }^{20}=+4.9\left(c 0.9, \mathrm{CHCl}_{3}\right)$; IR (film) 3489, 3313, 2119, 1689, $1645 \mathrm{~cm}^{-1} ;{ }^{1} \mathrm{H} \mathrm{NMR}\left(300 \mathrm{MHz}, \mathrm{CDCl}_{3}\right) \delta 9.45(\mathrm{~s}, 1 \mathrm{H}), 6.64(\mathrm{t}, J=9.9 \mathrm{~Hz}$, $1 \mathrm{H}), 4.27(\mathrm{~m}, 1 \mathrm{H}), 3.88-3.78(\mathrm{~m}, 2 \mathrm{H}), 2.62(\mathrm{~m}, 1 \mathrm{H}), 2.39(\mathrm{~m}, 1 \mathrm{H}), 2.22(\mathrm{dt}, J=2.7,6.9 \mathrm{~Hz}, 2 \mathrm{H}), 2.00(\mathrm{t}, J=2.1 \mathrm{~Hz}, 1 \mathrm{H}), 1.90-1.80(\mathrm{~m}, 1 \mathrm{H}), 1.78$ $(\mathrm{s}, 3 \mathrm{H}), 1.75(\mathrm{~m}, 1 \mathrm{H}), 1.60(\mathrm{~m}, 1 \mathrm{H}), 1.52-1.40(\mathrm{~m}, 2 \mathrm{H}), 1.08(\mathrm{~d}, J=7.2 \mathrm{~Hz}, 3 \mathrm{H}), 0.91(\mathrm{~s}, 9 \mathrm{H}), 0.12(\mathrm{~s}, 6 \mathrm{H}) ;{ }^{13} \mathrm{C} \mathrm{NMR}\left(75 \mathrm{MHz}, \mathrm{CDCl}_{3}\right) \delta 194.96$, 151.07, 140.44, 83.64, 78.04, 69.33, 68.89, 38.43, 34.48, 33.92, 25.76, 24.45, 18.39, 17.85, 11.34, 9.39, -4.32, -4.88; ESI-MS m/z 353 (M + H) ${ }^{+}$; HRMS Calcd. for $\mathrm{C}_{20} \mathrm{H}_{36} \mathrm{O}_{3} \mathrm{SiNa}(\mathrm{M}+\mathrm{Na})^{+}$requires 375.2326, found 375.2326.

9b: $[\alpha]_{\mathrm{D}}{ }^{20}=-4.7\left(c 1.7, \mathrm{CHCl}_{3}\right) ;{ }^{1} \mathrm{H}$ NMR $\left(300 \mathrm{MHz}, \mathrm{CDCl}_{3}\right) \delta 9.46(\mathrm{~s}, 1 \mathrm{H}), 6.75(\mathrm{t}, J=6.3 \mathrm{~Hz}, 1 \mathrm{H}), 3.81(\mathrm{~m}, 2 \mathrm{H}), 3.40(\mathrm{~m}, 1 \mathrm{H}), 2.55(\mathrm{~m}, 2 \mathrm{H})$, 
$2.23(\mathrm{dt}, J=2.4,6.6 \mathrm{~Hz}, 2 \mathrm{H}), 1.99(\mathrm{t}, J=2.7 \mathrm{~Hz}, 1 \mathrm{H}), 1.79(\mathrm{~s}, 3 \mathrm{H}), 1.72-1.55(\mathrm{~m}, 5 \mathrm{H}), 0.93(\mathrm{~s}, 9 \mathrm{H}), 0.87(\mathrm{~d}, J=7.2 \mathrm{~Hz}, 3 \mathrm{H}), 0.12(\mathrm{~s}, 6 \mathrm{H}) ;{ }^{13} \mathrm{C}$ $\operatorname{NMR}\left(75 \mathrm{MHz}, \mathrm{CDCl}_{3}\right) \delta 195.12,151.19,140.57,84.13,75.99,73.27,68.64,42.76,34.10,33.37,25.83,23.14,18.48,17.90,13.13,9.45,-4.27$, -4.67. ESI-MS m/z $353(\mathrm{M}+\mathrm{H})^{+}$; HRMS Calcd. for $\mathrm{C}_{20} \mathrm{H}_{36} \mathrm{O}_{3} \mathrm{SiNa}(\mathrm{M}+\mathrm{Na})^{+}$requires 375.2326, found 375.2323.
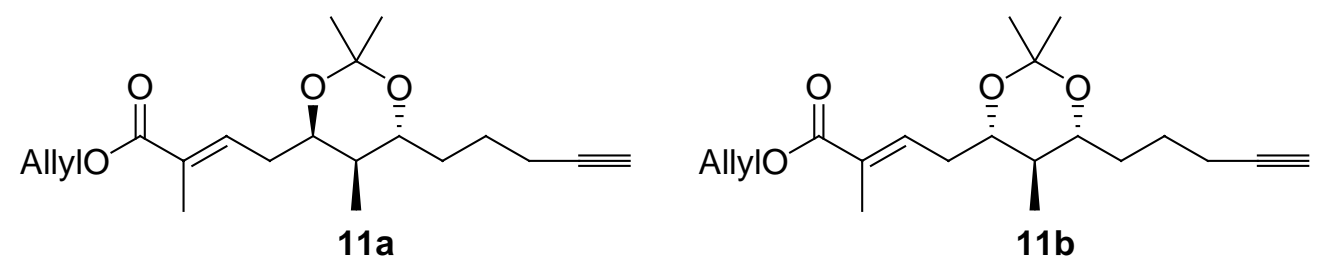

1,3-Diol acetonides 11. To the solution of $9 \mathbf{a}(80 \mathrm{mg}, 0.23 \mathrm{mmol})$ in tert-butyl alcohol $(2 \mathrm{~mL})$ and 2-methyl-2-butene (1 mL) was added the solution of sodium chlorite $(92 \mathrm{mg}, 1.0 \mathrm{mmol})$ and $\mathrm{NaH}_{2} \mathrm{PO}_{4}(61 \mathrm{mg}, 0.5 \mathrm{mmol})$ in $1 \mathrm{~mL}$ of water. The mixture was stirred for $2 \mathrm{~h}$ and extracted with ethyl acetate. The organic layer was dried over $\mathrm{Na}_{2} \mathrm{SO}_{4}$ and concentrated in vacuo. The residue was dissolved in DMF ( $1 \mathrm{~mL}$ ), followed by adding $\mathrm{KHCO}_{3}(45 \mathrm{mg}, 0.45 \mathrm{mmol})$ and Allyl bromide $(36 \mathrm{mg}, 0.3 \mathrm{mmol})$. The solution was stirred for $3 \mathrm{~h}$, diluted with ethyl acetate and washed with brine. The organic layer was dried over $\mathrm{Na}_{2} \mathrm{SO}_{4}$ and concentrated in vacuo. The residue was dissolved in $2 \mathrm{~mL}$ THF before TBAF ( $1 \mathrm{M}, 0.4 \mathrm{~mL}, 0.4 \mathrm{mmol})$ was added. After the resultant solution was stirred overnight, it was concentrated in vacuo and the residue was dissolved in $2 \mathrm{~mL} \mathrm{CH}_{2} \mathrm{Cl}_{2}$, followed by adding DMP (100 $\left.\mu \mathrm{L}, 0.4 \mathrm{mmol}\right)$ and TsOH (10 mg, $\left.0.06 \mathrm{mmol}\right)$. The solution was stirred for $1 \mathrm{~h}$, diluted with chloroform and washed with brine. The organic layer was dried over $\mathrm{Na}_{2} \mathrm{SO}_{4}$ and concentrated in vacuo. The residue was purified by chromatography eluting with $1: 9$ ethyl acetate/petroleum ether to give $\mathbf{1 1 a}$ in $63 \%$ yield for 4 steps. $[\alpha]_{\mathrm{D}}{ }^{20}=-2.1(c 0.6$, $\mathrm{CHCl} 3)$; IR (film) 
3309, 2118, 1715, 1650, $1458 \mathrm{~cm}^{-1} ;{ }^{1} \mathrm{H}$ NMR $\left(300 \mathrm{MHz} \mathrm{CDCl}_{3}\right) \delta 6.80(\mathrm{t}, J=6.3 \mathrm{~Hz}, 1 \mathrm{H}), 6.00(\mathrm{~m}, 1 \mathrm{H}), 5.29(\mathrm{~m}, 2 \mathrm{H}), 4.68(\mathrm{dd}, J=1.8,5.1 \mathrm{~Hz}$, 2H), $4.00(\mathrm{~m}, 1 \mathrm{H}), 3.30$ (t, $J=7.5 \mathrm{~Hz}, 1 \mathrm{H}), 2.40-2.20(\mathrm{~m}, 4 \mathrm{H}), 2.00(\mathrm{t}, J=2.7 \mathrm{~Hz}, 1 \mathrm{H}), 1.90(\mathrm{~s}, 3 \mathrm{H}), 1.80-1.65(\mathrm{~m}, 3 \mathrm{H}), 1.59(\mathrm{~m}, 2 \mathrm{H}), 1.38(\mathrm{~s}$, $6 \mathrm{H}), 0.90(\mathrm{~d}, J=6.9 \mathrm{~Hz}, 3 \mathrm{H}) ;{ }^{13} \mathrm{C} \mathrm{NMR}\left(75 \mathrm{MHz}, \mathrm{CDCl}_{3}\right) \delta 167.57,138.92,132.56,129.04,117.57,100.75,84.35,74.39,68.46,68.33,65.09$,

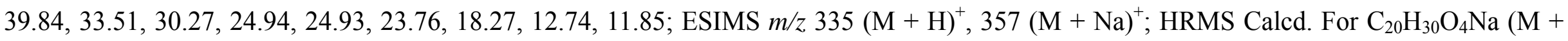
$\mathrm{Na})^{+}$requires 357.2036 , found 357.2035 .

Following the same procedure from $9 \mathbf{a}$ to $11 a, 11 b$ was synthesized from $9 \mathbf{b}$ in $60 \%$ yield. $[\alpha]_{\mathrm{D}}{ }^{20}=+3.8\left(c 0.4, \mathrm{CHCl}_{3}\right)$; $\mathrm{IR}_{(\mathrm{film})} 3305$, 2117, 1713, 1650, 1456, $1380 \mathrm{~cm}^{-1}$; ${ }^{1} \mathrm{H}$ NMR $\left(300 \mathrm{MHz}, \mathrm{CDCl}_{3}\right) \delta 6.92(\mathrm{t}, J=6.9 \mathrm{~Hz}, 1 \mathrm{H}), 5.99(\mathrm{~m}, 1 \mathrm{H}), 5.30(\mathrm{~m}, 2 \mathrm{H}), 4.67(\mathrm{~d}, J=5.7 \mathrm{~Hz}, 2 \mathrm{H})$, $3.62(\mathrm{~m}, 1 \mathrm{H}), 3.48(\mathrm{~m}, 1 \mathrm{H}), 2.49(\mathrm{~m}, 1 \mathrm{H}), 2.33(\mathrm{~m}, 1 \mathrm{H}), 2.21(\mathrm{~m}, 2 \mathrm{H}), 1.97(\mathrm{t}, J=2.7 \mathrm{~Hz}, 1 \mathrm{H}), 1.87(\mathrm{~s}, 3 \mathrm{H}), 1.80-1.70(\mathrm{~m}, 2 \mathrm{H}), 1.62-1.25(\mathrm{~m}$, 3H), $1.43(\mathrm{~s}, 3 \mathrm{H}), 1.38(\mathrm{~s}, 3 \mathrm{H}), 0.82(\mathrm{~d}, J=6.6 \mathrm{~Hz}, 3 \mathrm{H}) ;{ }^{13} \mathrm{C} \mathrm{NMR}\left(75 \mathrm{MHz}, \mathrm{CDCl}_{3}\right) \delta$ 167.66, 139.04, 132.61, 128.82, 117.53, 98.00, 84.50, 73.72, 73.49, 68.28, 65.05, 38.24, 32.77, 32.00, 30.06, 23.99, 19.58, 18.23, 12.64, 12.32; ESIMS m/z $335(\mathrm{M}+\mathrm{H})^{+}, 352\left(\mathrm{M}+\mathrm{NH}_{4}\right)^{+} ; \mathrm{HRMS}$ Calcd. for $\mathrm{C}_{20} \mathrm{H}_{30} \mathrm{O}_{4} \mathrm{Na}(\mathrm{M}+\mathrm{Na})^{+}$requires 357.2036, found 357.2039.

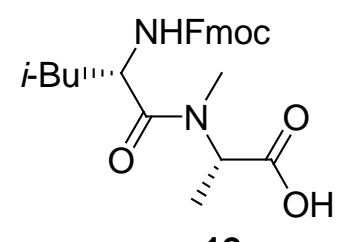

12

Fmoc-L-Ile-N-Me-Ala-OH 12. Fomc- $N$-Me-Ala-OBn $(1.8 \mathrm{~g}$, $4.3 \mathrm{mmol})$ was dissolved in $\mathrm{CH}_{3} \mathrm{CN}(6 \mathrm{~mL})$ and diethylamine $(3 \mathrm{~mL})$. The solution was stirred for $10 \mathrm{~min}$ and concentrated in vacuo. To the solution of the residue in $\mathrm{CH}_{2} \mathrm{Cl}_{2}(10 \mathrm{~mL})$ were sequentially added 
$N$-Fmoc-L-Ile $(1.55 \mathrm{~g}, 4.4 \mathrm{mmol})$, BEP $(1.8 \mathrm{~g}, 6.6 \mathrm{mmol})$ and DIPEA $(1.5 \mathrm{~mL}, 8.6 \mathrm{mmol})$ at $0{ }^{\circ} \mathrm{C}$ under nitrogen. The solution was stirred overnight and concentrated in vacuo. The residue was purified by chromatography eluting with 1:4 ethyl acetate/petroleum ether to give $1.83 \mathrm{~g}$ of dipeptide.

A solution of the above dipeptide $(1.6 \mathrm{~g}, 3.0 \mathrm{mmol})$ in methanol $(20 \mathrm{~mL})$ was hydrogenated for $6 \mathrm{~h}$ at $1 \mathrm{~atm}$ in the presence of $10 \% \mathrm{Pd} / \mathrm{C}$ (160 mg). The solution was filtrated and concentrated $\mathrm{n}$ vacuo. The residue was purified by chromatography eluting with 2:1ethyl acetate/methanol to give $1.2 \mathrm{~g}$ of $\mathbf{1 2}$ in $72 \%$ yield for 2 steps. $[\alpha]_{\mathrm{D}}{ }^{20}=-38.4\left(c 0.8, \mathrm{CHCl}_{3}\right.$ ); IR (film) $3297,3067,1717,1645,1608 \mathrm{~cm}^{-1} ;{ }^{1} \mathrm{H}$ NMR $\left(300 \mathrm{MHz}, \mathrm{CDCl}_{3}\right) \delta 10.60(\mathrm{br} \mathrm{s}, 1 \mathrm{H}), 7.77(\mathrm{~d}, J=7.5 \mathrm{~Hz}, 2 \mathrm{H}), 7.61(\mathrm{~m}, 2 \mathrm{H}), 7.40(\mathrm{t}, J=7.5 \mathrm{~Hz}, 2 \mathrm{H}), 7.30(\mathrm{t}, J=7.2 \mathrm{~Hz}, 2 \mathrm{H}), 6.21(\mathrm{~d}, J=$ $9.0 \mathrm{~Hz}, 1 \mathrm{H}), 5.28(\mathrm{~d}, J=6.9 \mathrm{~Hz}, 1 \mathrm{H}), 4.58(\mathrm{t}, J=8.7 \mathrm{~Hz}, 1 \mathrm{H}), 4.44-4.17(\mathrm{~m}, 3 \mathrm{H}), 3.07(\mathrm{~s}, 3 \mathrm{H}), 1.80(\mathrm{~m}, 1 \mathrm{H}), 1.60(\mathrm{~m}, 1 \mathrm{H}), 1.40(\mathrm{~d}, J=6.9 \mathrm{~Hz}$, $3 \mathrm{H}), 1.15(\mathrm{~m}, 1 \mathrm{H}), 0.97(\mathrm{~d}, \mathrm{~J}=6.9 \mathrm{~Hz}, 3 \mathrm{H}), 0.88(\mathrm{t}, \mathrm{J}=7.5 \mathrm{~Hz}, 3 \mathrm{H}) ;{ }^{13} \mathrm{C} \mathrm{NMR}\left(75 \mathrm{MHz}, \mathrm{CDCl}_{3}\right) \delta 173.31,156.52,143.85,143.79,141.24$, $127.64,126.98,125.11,119.89,67.01,60.39,55.18,47.15,37.66,31.70,24.15,24.11,15.32,14.07,11.04 ;$ ESI-MS $m / z 461(\mathrm{M}+\mathrm{H})^{+}, 477(\mathrm{M}+$ $\mathrm{K})^{+}$; HRMS Calcd. for $\mathrm{C}_{25} \mathrm{H}_{30} \mathrm{~N}_{2} \mathrm{O}_{5} \mathrm{Na}(\mathrm{M}+\mathrm{Na})^{+}$requires 461.2047, found 461.2050.

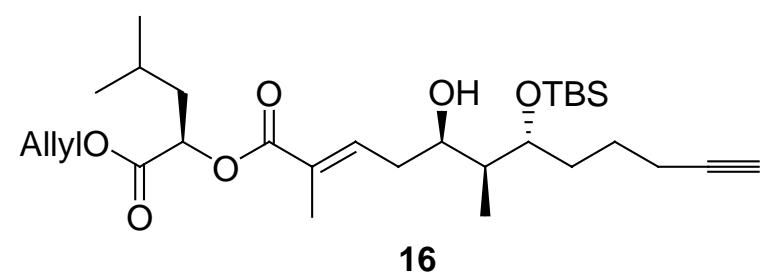


Ester 16. To the solution of $9 \mathbf{a}(400 \mathrm{mg}, 1.14 \mathrm{mmol})$ in tert-butyl alcohol $(6 \mathrm{~mL})$ and 2-methyl-2-butene $(3 \mathrm{~mL})$ was added a solution of sodium chlorite $(460 \mathrm{mg}, 5.0 \mathrm{mmol})$ and $\mathrm{NaH}_{2} \mathrm{PO}_{4}(305 \mathrm{mg}, 2.5 \mathrm{mmol})$ in $3 \mathrm{~mL}$ of water. The mixture was stirred for $2 \mathrm{~h}$ and extracted with ethyl acetate. The organic layer was dried over $\mathrm{Na}_{2} \mathrm{SO}_{4}$ and concentrated in vacuo. The residue was dissolved in dry dichloromethane (5 mL). To this resultant solution were added allyl ester 15 (205 mg, $1.19 \mathrm{mmol})$, EDCI (261 mg, $1.36 \mathrm{mmol})$ and DMAP (139 mg, $1.14 \mathrm{mmol})$. After the solution was stirred for $2 \mathrm{~h}$, it was washed with brine. The organic layer was dried over $\mathrm{Na}_{2} \mathrm{SO}_{4}$ and concentrated in vacuo. The residue was purified by chromatography eluting with $1: 9$ ethyl acetate/petroleum ether to give $\mathbf{1 6}$ in $100 \%$ yield for 2 steps. $[\alpha]_{\mathrm{D}}{ }^{20}=+4.4\left(c 1.3, \mathrm{CHCl}_{3}\right)$; IR (film) 3502, 3313, 2119, 1758, 1718, 1650, $1472 \mathrm{~cm}^{-1}$; ${ }^{1} \mathrm{H}$ NMR $\left(300 \mathrm{MHz}, \mathrm{CDCl}_{3}\right) \delta 6.87(\mathrm{t}, J=6.3 \mathrm{~Hz}, 1 \mathrm{H}), 5.90(\mathrm{~m}, 1 \mathrm{H}), 5.30(\mathrm{~m}, 2 \mathrm{H}), 5.09$ $(\mathrm{dd}, J=3.9,9.6 \mathrm{~Hz}, 1 \mathrm{H}), 4.64(\mathrm{dt}, J=1.5,5.7 \mathrm{~Hz}, 2 \mathrm{H}), 4.22(\mathrm{t}, J=6.6 \mathrm{~Hz}, 1 \mathrm{H}), 3.70(\mathrm{~m}, 2 \mathrm{H}), 2.46(\mathrm{~m}, 1 \mathrm{H}), 2.30(\mathrm{~m}, 1 \mathrm{H}), 2.21(\mathrm{~m}, 2 \mathrm{H}), 1.98(\mathrm{t}$, $J=2.4 \mathrm{~Hz}, 1 \mathrm{H}), 1.91(\mathrm{~s}, 3 \mathrm{H}), 1.86-1.70(\mathrm{~m}, 4 \mathrm{H}), 1.58-1.40(\mathrm{~m}, 4 \mathrm{H}), 1.04(\mathrm{~d}, J=6.9 \mathrm{~Hz}, 3 \mathrm{H}), 0.98(\mathrm{~d}, J=6.6 \mathrm{~Hz}, 3 \mathrm{H}), 0.95(\mathrm{~d}, J=6.3 \mathrm{~Hz}, 3 \mathrm{H})$, $0.91(\mathrm{~s}, 9 \mathrm{H}), 0.12(\mathrm{~s}, 6 \mathrm{H}) ;{ }^{13} \mathrm{C} \mathrm{NMR}\left(75 \mathrm{MHz}, \mathrm{CDCl}_{3}\right) \delta 170.56,167.30,139.77,131.66,128.63,118.42,83.72,78.04,71.16,69.41,68.91$, $65.59,39.83,37.98,34.18,33.86,25.81,24.77,24.38,23.03,21.66,18.42,17.90,12.64,11.15,-4.30,-4.84$; ESIMS m/z $523(\mathrm{M}+\mathrm{H})^{+}, 540(\mathrm{M}$

$+\mathrm{Na})^{+}$; HRMS Calcd. for $\mathrm{C}_{29} \mathrm{H}_{51} \mathrm{O}_{6} \mathrm{Si}(\mathrm{M}+\mathrm{H})^{+}$requires 523.3449, found 523.3452.

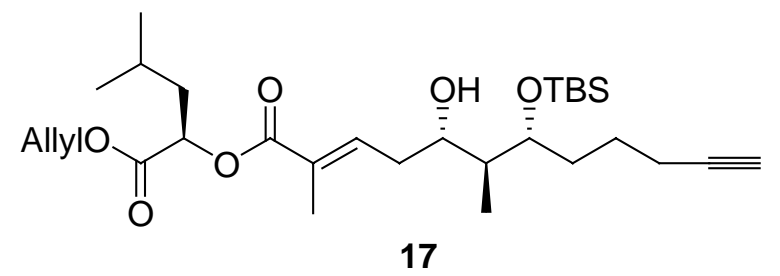


Ester 17. To a solution of $\mathbf{1 6}(310 \mathrm{mg}, 0.59 \mathrm{mmol})$ in $5 \mathrm{~mL}$ dry dichloromethane was added Dess-Martin reagent (378 $\mathrm{mg}, 0.89 \mathrm{mmol})$. The mixture was stirred overnight and quenched with saturated $\mathrm{Na}_{2} \mathrm{~S}_{2} \mathrm{O}_{3}$. The water layer was extracted with chloroform and the combined organic layers were dried over $\mathrm{Na}_{2} \mathrm{SO}_{4}$ and concentrated in vacuo. The residue was purified by chromatography eluting with 1:7 ethyl acetate/petroleum ether to give crude ketone.

To a solution of the above ketone $(320 \mathrm{mg}, 0.61 \mathrm{mmol})$ in methanol $(5 \mathrm{~mL})$ was added $\mathrm{NaBH}_{4}(108 \mathrm{mg}, 2.8 \mathrm{mmol})$ at $-50{ }^{\circ} \mathrm{C}$ under nitrogen. The solution was stirred for $1 \mathrm{~h}$, quenched with saturated $\mathrm{NH}_{4} \mathrm{Cl}$ and extracted with ethyl acetate. The organic layer were dried over $\mathrm{Na}_{2} \mathrm{SO}_{4}$ and concentrated in vacuo. The residue was purified by chromatography eluting with 1:7 ethyl acetate/petroleum ether to give 300 mg of 17 in $91 \%$ yield for 2 steps. $[\alpha]_{\mathrm{D}}{ }^{20}=+1.0\left(c\right.$ 1.6, $\left.\mathrm{CHCl}_{3}\right)$; IR (film) $3516,3313,2117,1758,1717,1649,1472 \mathrm{~cm}^{-1} ;{ }^{1} \mathrm{H} \mathrm{NMR}\left(300 \mathrm{MHz}, \mathrm{CDCl}_{3}\right)$ $\delta 7.03(\mathrm{t}, J=6.3 \mathrm{~Hz}, 1 \mathrm{H}), 5.90(\mathrm{~m}, 1 \mathrm{H}), 5.30(\mathrm{~m}, 2 \mathrm{H}), 5.08(\mathrm{dd}, J=3.9,9.3 \mathrm{~Hz}, 1 \mathrm{H}), 4.65(\mathrm{~d}, J=5.7 \mathrm{~Hz}, 2 \mathrm{H}), 3.83(\mathrm{~m}, 1 \mathrm{H}), 3.71(\mathrm{~m}, 1 \mathrm{H}), 2.86$ $(\mathrm{d}, J=3.3 \mathrm{~Hz}, 1 \mathrm{H}), 2.48(\mathrm{~m}, 1 \mathrm{H}), 2.35(\mathrm{~m}, 1 \mathrm{H}), 2.21(\mathrm{~m}, 2 \mathrm{H}), 1.97(\mathrm{t}, J=2.1 \mathrm{~Hz}, 1 \mathrm{H}), 1.90(\mathrm{~s}, 3 \mathrm{H}), 1.88-1.66(\mathrm{~m}, 4 \mathrm{H}), 1.62(\mathrm{~m}, 4 \mathrm{H}), 0.98(\mathrm{~d}, J$ $=6.3 \mathrm{~Hz}, 3 \mathrm{H}), 0.95(\mathrm{~d}, J=6.6 \mathrm{~Hz}, 3 \mathrm{H}), 0.92(\mathrm{~s}, 9 \mathrm{H}), 0.86(\mathrm{~d}, J=6.6 \mathrm{~Hz}, 3 \mathrm{H}), 0.11(\mathrm{~s}, 6 \mathrm{H}) ;{ }^{13} \mathrm{C} \mathrm{NMR}\left(75 \mathrm{MHz} \mathrm{CDCl}_{3}\right) \delta 170.64,167.30$, $140.15,131.67,128.79,118.45,84.25,75.08,73.17,71.21,68.57,65.60,43.13,39.86,34.20,32.80,25.87,24.81,23.61,23.04,21.71,18.50$, 18.02, 12.67, 12.53, -4.30, -4.61; ESI-MS m/z $523(\mathrm{M}+\mathrm{H})^{+}, 540(\mathrm{M}+\mathrm{Na})^{+}$; HRMS Calcd. for $\mathrm{C}_{29} \mathrm{H}_{50} \mathrm{O}_{6} \mathrm{SiNa}(\mathrm{M}+\mathrm{Na})^{+}$requires 545.3269 , found 545.3268 . 


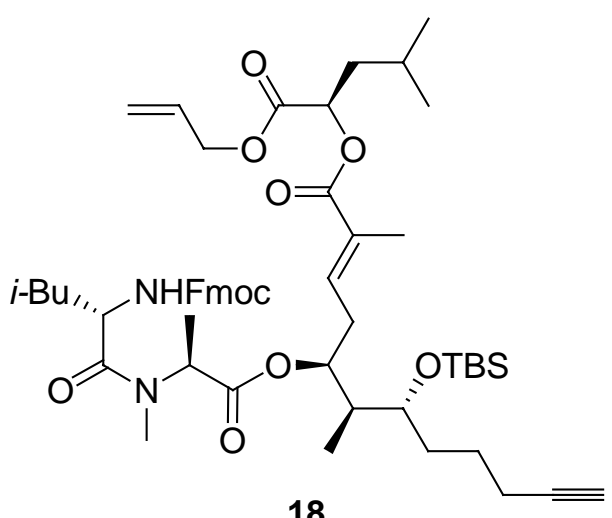

18

Coupling of 17 and 12. To a solution of $12(300 \mathrm{mg}, 0.68 \mathrm{mmol})$ in $1 \mathrm{~mL}$ of dry benzene was added 2,4,6-trichlorobenzoyl chloride $(0.16 \mathrm{~mL}, 1.02 \mathrm{mmol})$ and DIPEA $(0.23 \mathrm{~mL}, 1.36 \mathrm{mmol})$. The solution was stirred for $10 \mathrm{~min}$ and then added a solution of 17 (320 mg, 0.61 mmol) and DMAP (167 mg, $1.36 \mathrm{mmol})$ in $1 \mathrm{~mL}$ of benzene. The mixture was stirred overnight and quenched with brine. The water phase was extracted with ethyl acetate. The combined organic layers were dried over $\mathrm{Na}_{2} \mathrm{SO}_{4}$ and concentrated in vacuo. The residue was purified by chromatography eluting with 1:4 ethyl acetate/petroleum to give $491 \mathrm{mg}$ of $\mathbf{1 8}$ in $85 \%$ yield. [ $\alpha]_{\mathrm{D}}{ }^{20}=+8.3\left(c 1.0, \mathrm{CHCl}_{3}\right)$; IR (film) 3308,2116 , 1718, 1647, 1521, $1452 \mathrm{~cm}^{-1}$; ${ }^{1} \mathrm{H}$ NMR $\left(300 \mathrm{MHz}, \mathrm{CDCl}_{3}\right) \delta 7.77(\mathrm{~d}, J=7.2 \mathrm{~Hz}, 2 \mathrm{H}), 7.61(\mathrm{~d}, J=6.9 \mathrm{~Hz}, 2 \mathrm{H}), 7.41(\mathrm{t}, J=7.5 \mathrm{~Hz}, 2 \mathrm{H}), 7.32(\mathrm{t}, J$ $=7.5 \mathrm{~Hz}, 2 \mathrm{H}), 6.77(\mathrm{~m}, 1 \mathrm{H}), 5.90(\mathrm{~m}, 1 \mathrm{H}), 5.55(\mathrm{t}, J=8.4 \mathrm{~Hz}, 1 \mathrm{H}), 5.30(\mathrm{~m}, 2 \mathrm{H}), 5.10(\mathrm{~m}, 2 \mathrm{H}), 4.63(\mathrm{~d}, J=6.0 \mathrm{~Hz}, 2 \mathrm{H}), 4.60-4.18(\mathrm{~m}, 4 \mathrm{H}), 3.60$ (m, 1H), $3.05(\mathrm{~s}, 3 \mathrm{H}), 2.50(\mathrm{~m}, 2 \mathrm{H}), 2.20(\mathrm{~m}, 2 \mathrm{H}), 1.97(\mathrm{t}, J=2.7 \mathrm{~Hz}, 1 \mathrm{H}), 1.89(\mathrm{~s}, 3 \mathrm{H}), 1.85-1.70(\mathrm{~m}, 4 \mathrm{H}), 1.60-1.45(\mathrm{~m}, 5 \mathrm{H}), 1.40(\mathrm{~m}, 3 \mathrm{H})$, 1.35-1.10 (m, 3H), 1.05-0.80 (m, 24H), $0.05(\mathrm{~m}, 6 \mathrm{H})$; ESIMS m/z $965(\mathrm{M}+\mathrm{Na})^{+}$; HRMS Calcd. for $\mathrm{C}_{54} \mathrm{H}_{78} \mathrm{~N}_{2} \mathrm{O}_{10} \mathrm{SiNa}\left(\mathrm{M}+\mathrm{Na}^{+}\right.$requires 965.5318 , found 965.5314 . 


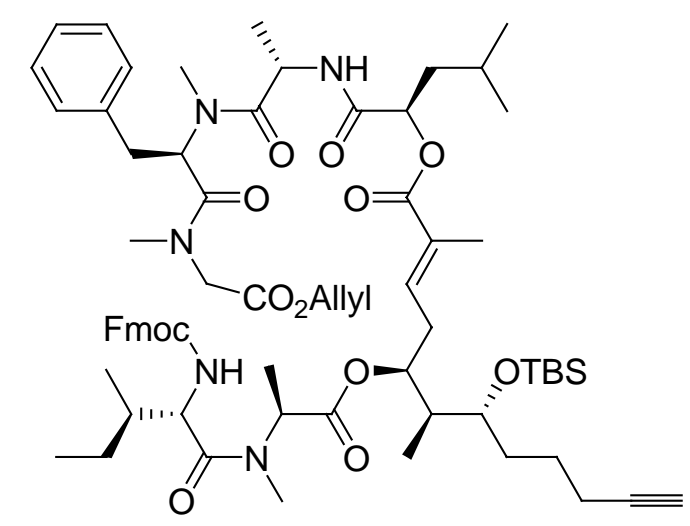

20

Coupling of liberated 18 and tripeptide 19. To a solution of $18(266 \mathrm{mg}, 0.29 \mathrm{mmol})$ in $4 \mathrm{~mL}$ of dry $\mathrm{THF}$ were added $\mathrm{Pd}\left(\mathrm{PPh}_{3}\right)_{4}(34$ $\mathrm{mg}, 0.029 \mathrm{mmol})$ and NMA $(63 \mu \mathrm{L}, 0.58 \mathrm{mmol})$ under nitrogen. The solution was stirred for $2 \mathrm{~h}$ and diluted with ethyl acetate. The organic phase was washed with $1 \mathrm{~N}$ hydrochloric acid and $10 \%$ aqueous $\mathrm{NaHCO}_{3}$. The organic layer was dried over $\mathrm{NaSO}_{4}$ and concentrated in vacuo.

A solution of $19(160 \mathrm{mg}, 0.27 \mathrm{mmol})$ in $\mathrm{CH}_{3} \mathrm{CN}(2 \mathrm{~mL})$ and diethylamine $(1 \mathrm{~mL})$ was stirred for 10 min and concentrated in vacuo. The residue was dissolved in $2 \mathrm{~mL}$ of dry dichloromethane. To this solution were added a solution of liberated $\mathbf{1 8}$ in dichloromethane, HATU (156 $\mathrm{mg}, 0.41 \mathrm{mmol})$ and DIPEA $(94 \mu \mathrm{L}, 0.55 \mathrm{mmol})$ at $0{ }^{\circ} \mathrm{C}$ under nitrogen. The solution was stirred overnight and concentrated in vacuo. The residue was purified by chromatography eluting with $1: 1$ ethyl acetate/petroleum to give $208 \mathrm{mg}$ of 20 in $66 \%$ yield for 2 steps. [ $\alpha]_{\mathrm{D}}{ }^{20}=+38.4(c$ 1.9, $\left.\mathrm{CHCl}_{3}\right) ;{ }^{1} \mathrm{H} \mathrm{NMR}\left(300 \mathrm{MHz}, \mathrm{CDCl}_{3}\right) \delta 7.77(\mathrm{~d}, J=7.8 \mathrm{~Hz}, 2 \mathrm{H}), 7.60(\mathrm{~m}, 2 \mathrm{H}), 7.40(\mathrm{t}, J=7.8 \mathrm{~Hz}, 2 \mathrm{H}), 7.35-7.15(\mathrm{~m}, 7 \mathrm{H}), 6.77(\mathrm{~m}, 2 \mathrm{H})$, 
5.98-5.55 (m, 3H), $5.30(\mathrm{~m}, 2 \mathrm{H}), 5.12(\mathrm{~m}, 2 \mathrm{H}), 4.80-4.15(\mathrm{~m}, 9 \mathrm{H}), 3.94(\mathrm{~m}, 1 \mathrm{H}), 3.68(\mathrm{~m}, 1 \mathrm{H}), 3.15(\mathrm{~m}, 1 \mathrm{H}), 3.00(\mathrm{~m}, 9 \mathrm{H}), 2.50(\mathrm{~m}, 2 \mathrm{H}), 2.19$ $(\mathrm{m}, 2 \mathrm{H}), 1.98(\mathrm{~m}, 2 \mathrm{H}), 1.88(\mathrm{~s}, 3 \mathrm{H}), 1.82-1.48(\mathrm{~m}, 9 \mathrm{H}), 1.38(\mathrm{~m}, 3 \mathrm{H}), 1.05-0.66(\mathrm{~m}, 29 \mathrm{H}), 0.07(\mathrm{~s}, 3 \mathrm{H}), 0.04(\mathrm{~s}, 3 \mathrm{H})$; ESIMS m/z $1268(\mathrm{M}+\mathrm{Na})^{+}$; HRMS Calcd. for $\mathrm{C}_{70} \mathrm{H}_{99} \mathrm{~N}_{5} \mathrm{O}_{13} \mathrm{SiNa}(\mathrm{M}+\mathrm{Na})^{+}$requires 1268.6901, found 1268.6925.

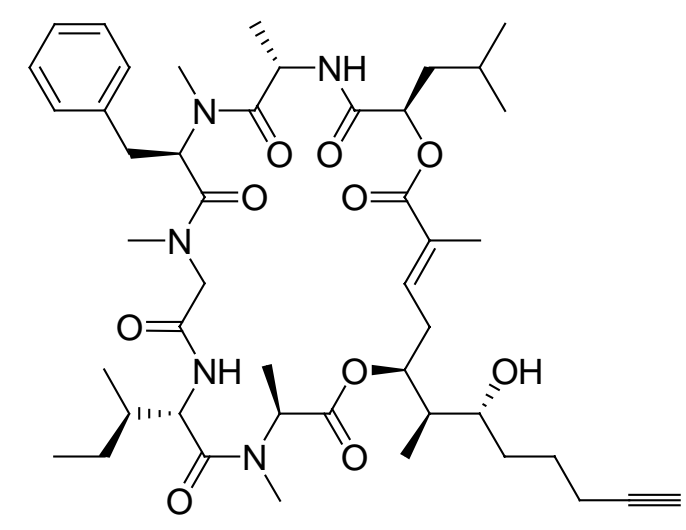

1

Cyclic depsipeptide 1. To a solution of $\mathbf{2 0}(40 \mathrm{mg}, 32 \mu \mathrm{mol})$ in $2 \mathrm{~mL}$ of dry THF was added $\left.\mathrm{Pd}\left(\mathrm{PPh}_{3}\right)_{4}(8 \mathrm{mg}, 6.4 \mu \mathrm{mol})\right)$ and NMA ((7 $\mu \mathrm{L}, 64 \mu \mathrm{mol}$ ) under nitrogen. The solution was stirred for $2 \mathrm{~h}$ and diluted with ethyl acetate. The organic phase was washed with $1 \mathrm{~N}$ hydrochloric acid and $10 \%$ aqueous $\mathrm{NaHCO}_{3}$. The organic layer was dried over $\mathrm{Na}_{2} \mathrm{SO}_{4}$ and concentrated in vacuo. The residue was dissolved in $\mathrm{CH}_{3} \mathrm{CN}(1 \mathrm{~mL})$ and diethylamine $(0.5 \mathrm{~mL})$. The solution was stirred for $10 \mathrm{~min}$ and concentrated in vacuo. The residue was dissolved in $16 \mathrm{~mL}$ of dry dichloromethane. To the solution was added HATU (36 mg, $96 \mu \mathrm{mol})$ and DIPEA $(30 \mu \mathrm{L}, 160 \mu \mathrm{mol})$ at $0{ }^{\circ} \mathrm{C}$ under nitrogen. The solution 
was stirred for 3 days and concentrated in vacuo. The residue was purified by chromatography eluting with 1:1 ethyl acetate/petroleum to give 9 mg of macrocyclization product.

To a solution of the above cyclic product $(10 \mathrm{mg}, 10.5 \mu \mathrm{mol})$ in $1 \mathrm{~mL}$ of $\mathrm{CH}_{3} \mathrm{CN}$ was added $50 \mu \mathrm{L}$ hydrofluoric acid. The mixture was stirred for $1 \mathrm{~h}$ and concentrated in vacuo. The residue was dissolved in ethyl acetate and washed with saturated $\mathrm{NaHCO}_{3}$ and brine. The organic layer was dried over $\mathrm{Na}_{2} \mathrm{SO}_{4}$ and concentrated in vacuo. The residue was purified by chromatography eluting with 4:1 ethyl acetate/petroleum to give $7 \mathrm{mg}$ of 1 in $25 \%$ yield for 4 steps. $[\alpha]_{\mathrm{D}}{ }^{20}=+18.3(c 0.15, \mathrm{MeOH}) ;{ }^{1} \mathrm{H} \mathrm{NMR}\left(500 \mathrm{MHz}, \mathrm{CD}_{3} \mathrm{OD}\right) \delta 7.65(\mathrm{~m}, 1 \mathrm{H}), 7.55(\mathrm{~m}, 1 \mathrm{H}), 7.24(\mathrm{t}, J=$ $7.3 \mathrm{~Hz}, 1 \mathrm{H}), 7.15(\mathrm{~d}, J=7.0 \mathrm{~Hz}, 2 \mathrm{H}), 7.10(\mathrm{t}, J=6.8 \mathrm{~Hz}, 2 \mathrm{H}), 6.76(\mathrm{~m}, 1 \mathrm{H}), 5.47(\mathrm{dd}, J=5.7,9.8 \mathrm{~Hz}, 1 \mathrm{H}), 5.05(\mathrm{~m}, 1 \mathrm{H}), 4.93(\mathrm{dd}, J=10.1,13.7$ $\mathrm{Hz}, 1 \mathrm{H}), 4.90(\mathrm{~m}, 1 \mathrm{H}), 4.51$ (q, $J=7.0 \mathrm{~Hz}, 1 \mathrm{H}), 4.21(\mathrm{~d}, J=18.7 \mathrm{~Hz}, 1 \mathrm{H}), 3.80(\mathrm{~m}, 1 \mathrm{H}), 3.48(\mathrm{~m}, 1 \mathrm{H}), 3.16(\mathrm{~s}, 3 \mathrm{H}), 3.11(\mathrm{~d}, J=18.6 \mathrm{~Hz}, 1 \mathrm{H})$, $3.03(\mathrm{~s}, 3 \mathrm{H}), 3.02(\mathrm{dd}, J=9.7,14.7 \mathrm{~Hz}, 1 \mathrm{H}), 2.95(\mathrm{~m}, 1 \mathrm{H}), 2.91(\mathrm{~s}, 3 \mathrm{H}), 2.82(\mathrm{~m}, 1 \mathrm{H}), 2.58(\mathrm{~m}, 1 \mathrm{H}), 2.20(\mathrm{t}, J=2.5 \mathrm{~Hz}, 1 \mathrm{H}), 2.19(\mathrm{~m}, 2 \mathrm{H}), 1.93$ $(\mathrm{s}, 3 \mathrm{H}), 1.86(\mathrm{~m}, 1 \mathrm{H}), 1.84(\mathrm{~m}, 1 \mathrm{H}), 1.81(\mathrm{~m}, 1 \mathrm{H}), 1.79(\mathrm{~m}, 1 \mathrm{H}), 1.58(\mathrm{~m}, 2 \mathrm{H}), 1.53(\mathrm{~m}, 2 \mathrm{H}), 1.49(\mathrm{~d}, J=7.5 \mathrm{~Hz}, 3 \mathrm{H}), 1.39(\mathrm{~m}, 1 \mathrm{H}), 1.37(\mathrm{~m}$, $1 \mathrm{H}), 1.33(\mathrm{~m}, 1 \mathrm{H}), 0.99$ (d, $J=7.3 \mathrm{~Hz}, 3 \mathrm{H}), 0.94(\mathrm{t}, J=7.4 \mathrm{~Hz}, 3 \mathrm{H}), 0.91(\mathrm{~d}, J=3.5 \mathrm{~Hz}, 3 \mathrm{H}), 0.89$ (d, $J=6.7 \mathrm{~Hz}, 3 \mathrm{H}), 0.85(\mathrm{~d}, J=7.1 \mathrm{~Hz}, 3 \mathrm{H})$, $0.83(\mathrm{~d}, J=7.2 \mathrm{~Hz}, 3 \mathrm{H})$; ESIMS $m / z 852(\mathrm{M}+\mathrm{H})^{+}, 874(\mathrm{M}+\mathrm{Na})^{+}$; HRMS Calcd. for $\mathrm{C}_{46} \mathrm{H}_{69} \mathrm{~N}_{5} \mathrm{O}_{10} \mathrm{SiNa}(\mathrm{M}+\mathrm{Na})^{+}$requires 874.4937 , found 874.4938 . 
${ }^{1}$ H NMR data comparison of synthetic 1 with natural palau'amine

\begin{tabular}{|c|c|}
\hline Synthetic 1 & Natural palau'amime \\
\hline $7.65(\mathrm{~m}, 1 \mathrm{H})$ & $8.57(\mathrm{~d}, J=6.8 \mathrm{~Hz}, 1 \mathrm{H})$ \\
\hline $7.55(\mathrm{~m}, 1 \mathrm{H})$ & $8.17(\mathrm{~d}, J=9.6 \mathrm{~Hz}, 1 \mathrm{H})$ \\
\hline $7.15(\mathrm{~d}, J=7.0 \mathrm{~Hz}, 2 \mathrm{H})$ & $7.16(\mathrm{t}, J=6.9 \mathrm{~Hz}, 2 \mathrm{H})$ \\
\hline $7.10(\mathrm{t}, J=6.8 \mathrm{~Hz}, 2 \mathrm{H})$ & $7.14(\mathrm{~d}, J=6.9 \mathrm{~Hz}, 2 \mathrm{H})$ \\
\hline $6.76(\mathrm{~m}, 1 \mathrm{H})$ & $6.84(\mathrm{~m}, 1 \mathrm{H})$ \\
\hline $4.93(\mathrm{dd}, J=10.1,13.7 \mathrm{~Hz}, 1 \mathrm{H})$ & $4.91(\mathrm{dd}, J=10.1,13.7 \mathrm{~Hz}, 1 \mathrm{H})$ \\
\hline $4.90(\mathrm{~m}, 1 \mathrm{H})$ & $4.89(\mathrm{t}, 1 \mathrm{H})$ \\
\hline $4.51(\mathrm{q}, J=7.0 \mathrm{~Hz}, 1 \mathrm{H})$ & $4.47(\mathrm{p}, 1 \mathrm{H})$ \\
\hline $4.21(\mathrm{~d}, J=18.7 \mathrm{~Hz}, 1 \mathrm{H})$ & $4.18(\mathrm{~d}, J=18.7 \mathrm{~Hz}, 1 \mathrm{H})$ \\
\hline $3.80(\mathrm{~m}, 1 \mathrm{H})$ & $3.84(\mathrm{q}, 1 \mathrm{H})$ \\
\hline $3.02(\mathrm{dd}, J=9.7,14.7 \mathrm{~Hz}, 1 \mathrm{H})$ & $3.01(\mathrm{dd}, J=9.9,14.5 \mathrm{~Hz}, 1 \mathrm{H})$ \\
\hline $2.95(\mathrm{~m}, 1 \mathrm{H})$ & $2.95(\mathrm{dd}, 1 \mathrm{H})$ \\
\hline $2.91(\mathrm{~s}, 3 \mathrm{H})$ & $2.87(\mathrm{~s}, 3 \mathrm{H})$ \\
\hline $2.82(\mathrm{~m}, 1 \mathrm{H})$ & $2.83(\mathrm{ddd}, 1 \mathrm{H})$ \\
\hline $2.58(\mathrm{~m}, 1 \mathrm{H})$ & $2.46(\mathrm{ddd}, 1 \mathrm{H})$ \\
\hline $2.20(\mathrm{t}, J=2.5 \mathrm{~Hz}, 1 \mathrm{H})$ & $2.20(\mathrm{t}, J=2.5 \mathrm{~Hz}, 1 \mathrm{H})$ \\
\hline
\end{tabular}




\begin{tabular}{|c|c|}
\hline $2.19(\mathrm{~m}, 2 \mathrm{H})$ & $2.19(\mathrm{dt}, 2 \mathrm{H})$ \\
$1.93(\mathrm{~s}, 3 \mathrm{H})$ & $1.93(\mathrm{~s}, 3 \mathrm{H})$ \\
$1.86(\mathrm{~m}, 1 \mathrm{H})$ & $1.86(\mathrm{~m}, 1 \mathrm{H})$ \\
$1.84(\mathrm{~m}, 1 \mathrm{H})$ & $1.87(\mathrm{~m}, 1 \mathrm{H})$ \\
$1.81(\mathrm{~m}, 1 \mathrm{H})$ & $1.84(\mathrm{~m}, 1 \mathrm{H})$ \\
$1.79(\mathrm{~m}, 1 \mathrm{H})$ & $1.79(\mathrm{~m}, 1 \mathrm{H}), 1.79(\mathrm{qdd})$ \\
$1.58(\mathrm{~m}, 2 \mathrm{H})$ & $1.65(\mathrm{~m}, 1 \mathrm{H}), 1.58(\mathrm{~m}, 1 \mathrm{H})$ \\
$1.53(\mathrm{~m}, 2 \mathrm{H})$ & $1.51(\mathrm{~m}, 1 \mathrm{H}), 1.48(\mathrm{~m}, 1 \mathrm{H})$ \\
$1.49(\mathrm{~d}, J=7.5 \mathrm{~Hz}, 3 \mathrm{H})$ & $1.44(\mathrm{~d}, J=6.7 \mathrm{~Hz}, 3 \mathrm{H})$ \\
$1.39(\mathrm{~m}, 1 \mathrm{H})$ & $1.41(\mathrm{~m}, 1 \mathrm{H})$ \\
$1.37(\mathrm{~m}, 1 \mathrm{H})$ & $1.37(\mathrm{~m}, 1 \mathrm{H})$ \\
$1.33(\mathrm{~m}, 1 \mathrm{H})$ & $1.32(\mathrm{~m}, 1 \mathrm{H})$ \\
$0.99(\mathrm{~d}, J=7.3 \mathrm{~Hz}, 3 \mathrm{H})$ & $0.95(\mathrm{~d}, J=6.6 \mathrm{~Hz}, 3 \mathrm{H})$ \\
$0.94(\mathrm{t}, J=7.4 \mathrm{~Hz}, 3 \mathrm{H})$ & $0.94(\mathrm{t}, J=7.4 \mathrm{~Hz}, 3 \mathrm{H})$ \\
$0.91(\mathrm{~d}, J=3.5 \mathrm{~Hz}, 3 \mathrm{H})$ & $0.91(\mathrm{~d}, J=6.0 \mathrm{~Hz}, 3 \mathrm{H})$ \\
$0.89(\mathrm{~d}, J=6.7 \mathrm{~Hz}, 3 \mathrm{H})$ & $0.88(\mathrm{~d}, J=6.6 \mathrm{~Hz}, 3 \mathrm{H})$ \\
$0.85(\mathrm{~d}, J=7.1 \mathrm{~Hz}, 3 \mathrm{H})$ & $0.85(\mathrm{~d}, J=7.0 \mathrm{~Hz}, 3 \mathrm{H})$ \\
$0.83(\mathrm{~d}, J=7.2 \mathrm{~Hz}, 3 \mathrm{H})$ & $0.82(\mathrm{~d}, J=6.8 \mathrm{~Hz}, 3 \mathrm{H})$ \\
\hline
\end{tabular}


$\Delta$

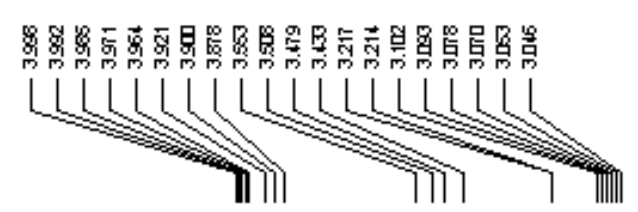

$\square$

$\nabla$

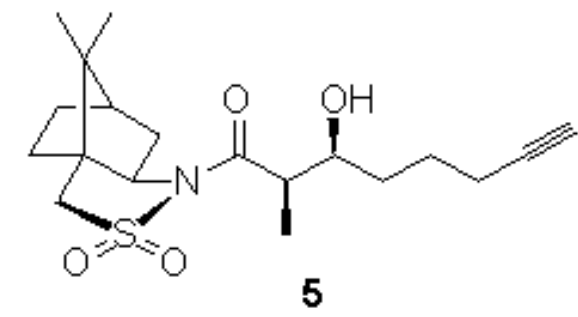

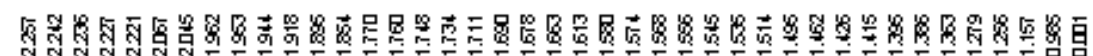

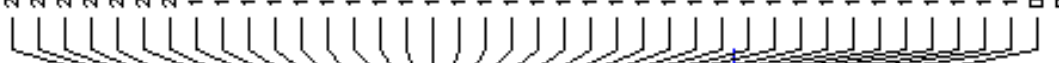

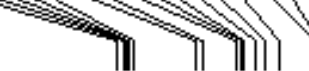

(IIITाiा

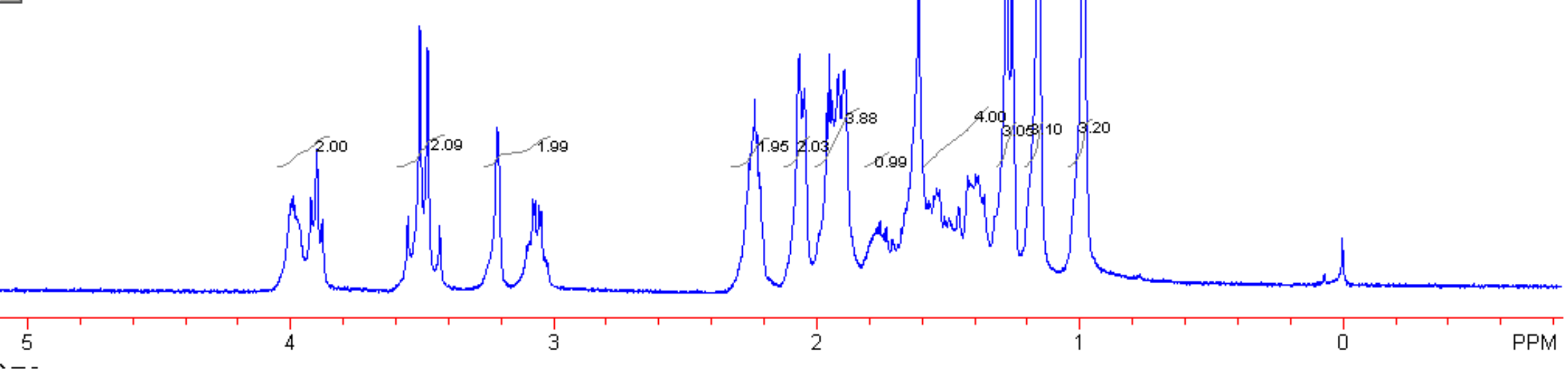




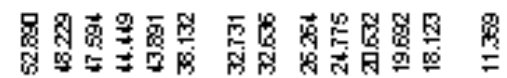

141

IVTy
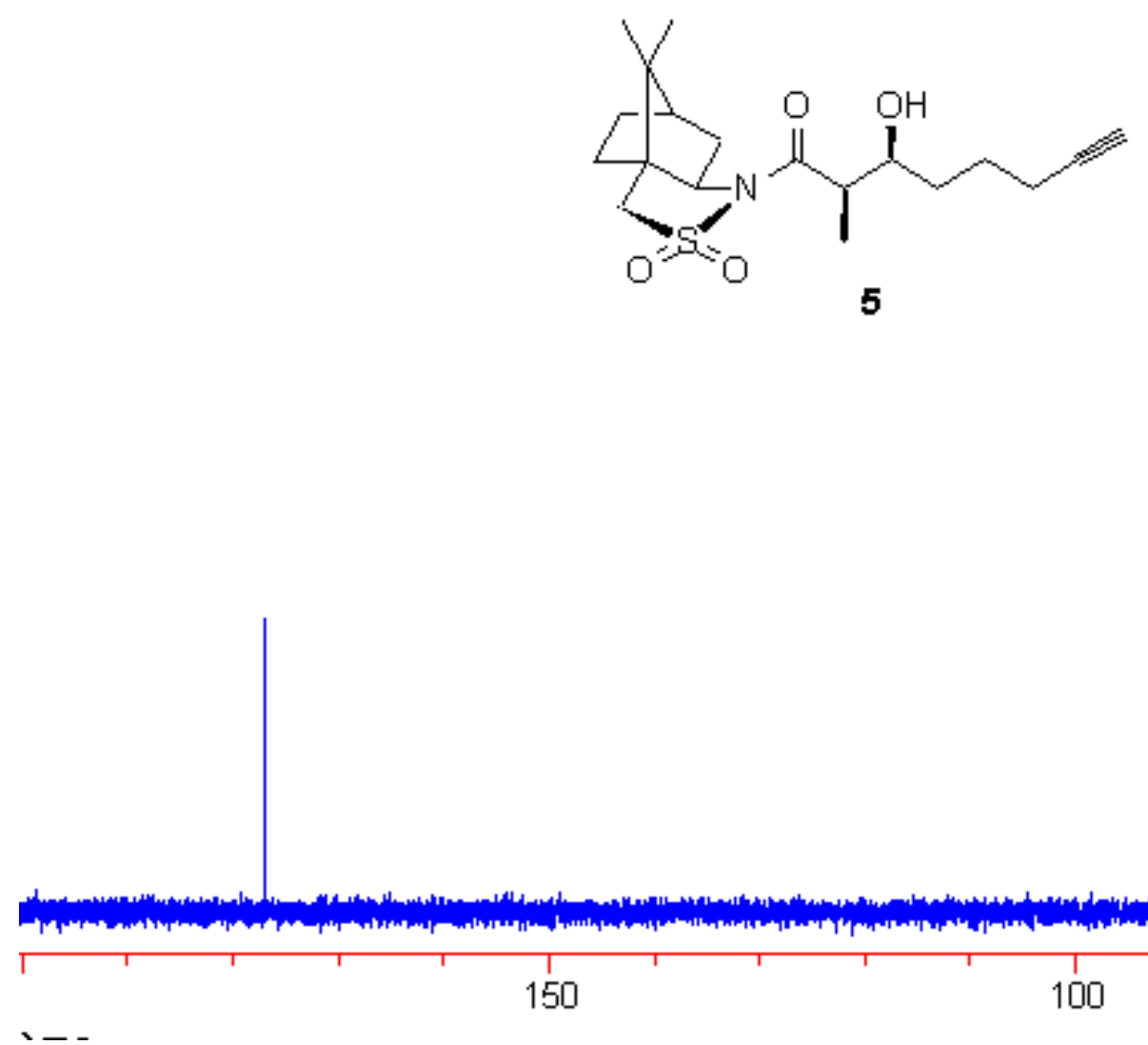
$\Delta$

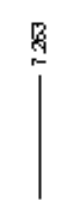

$\sqcup$

$\nabla$

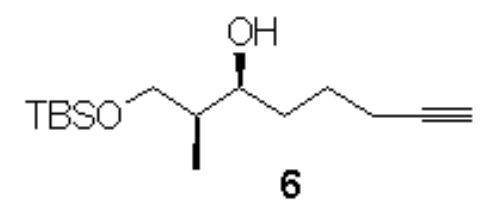

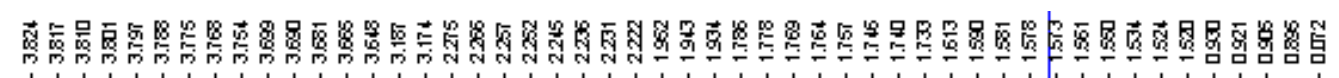

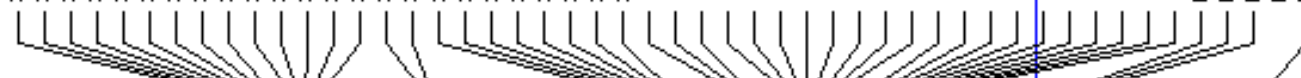

1

? Wili in

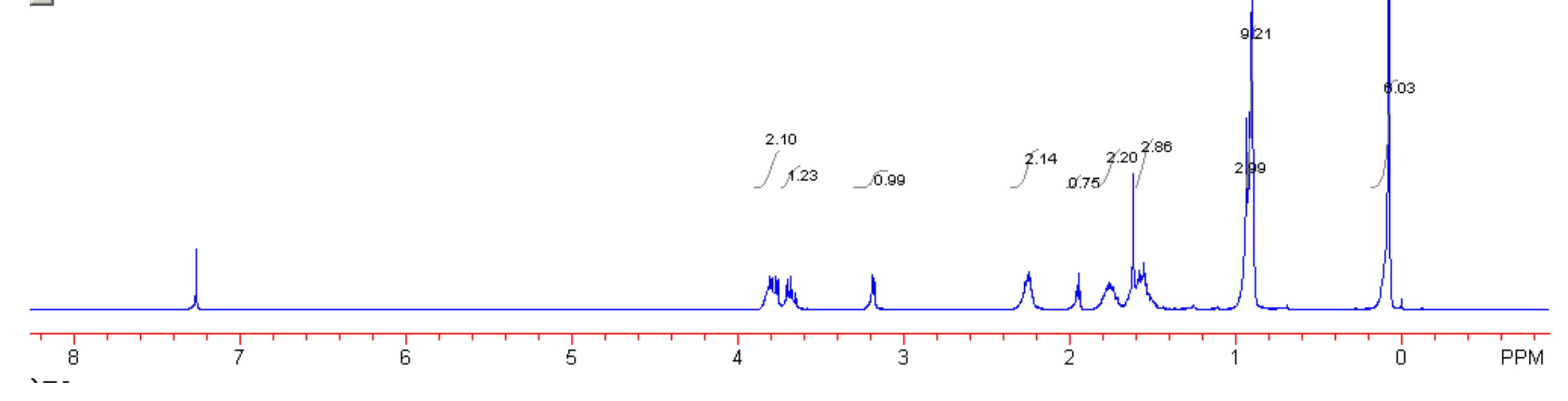



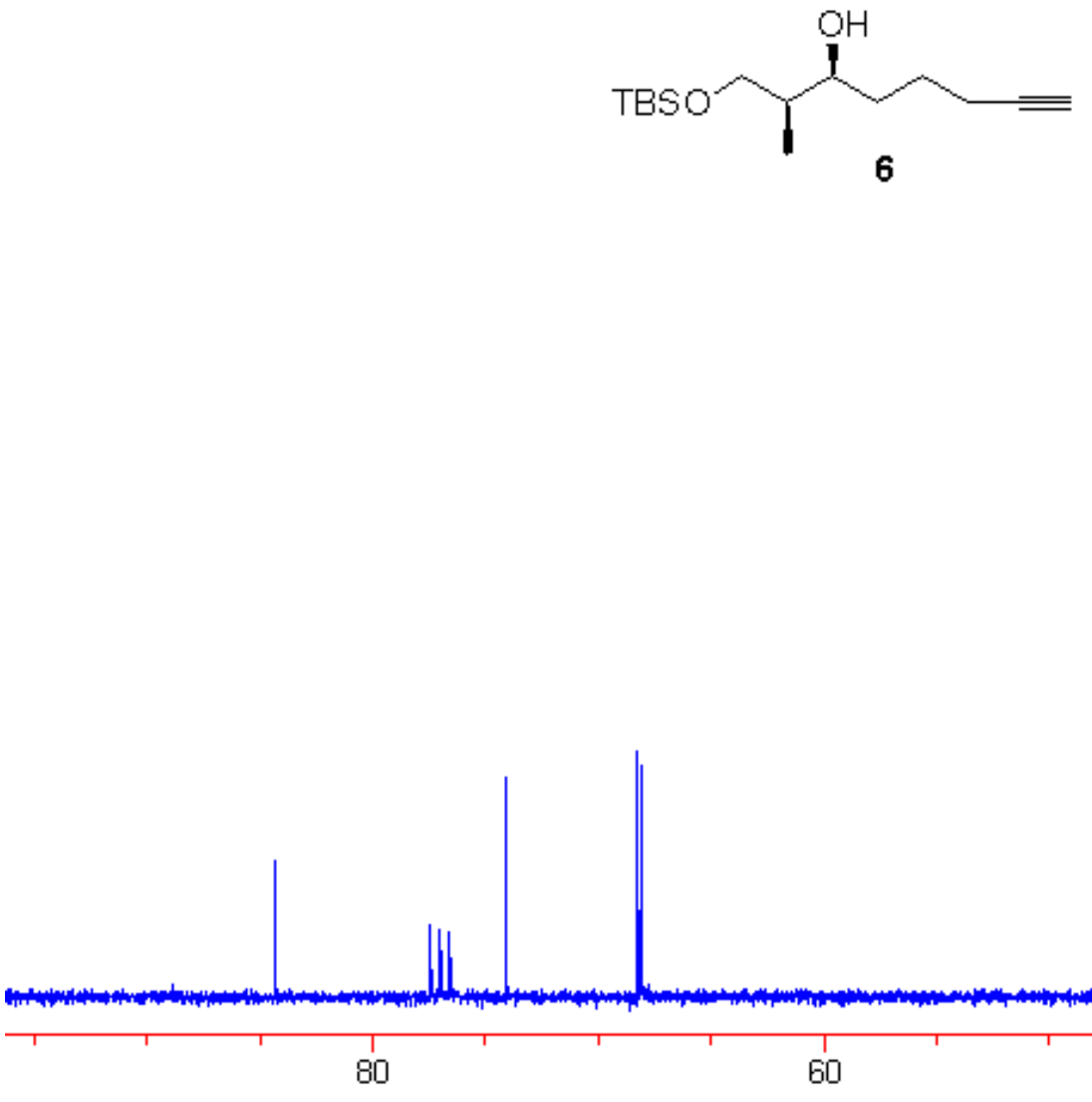


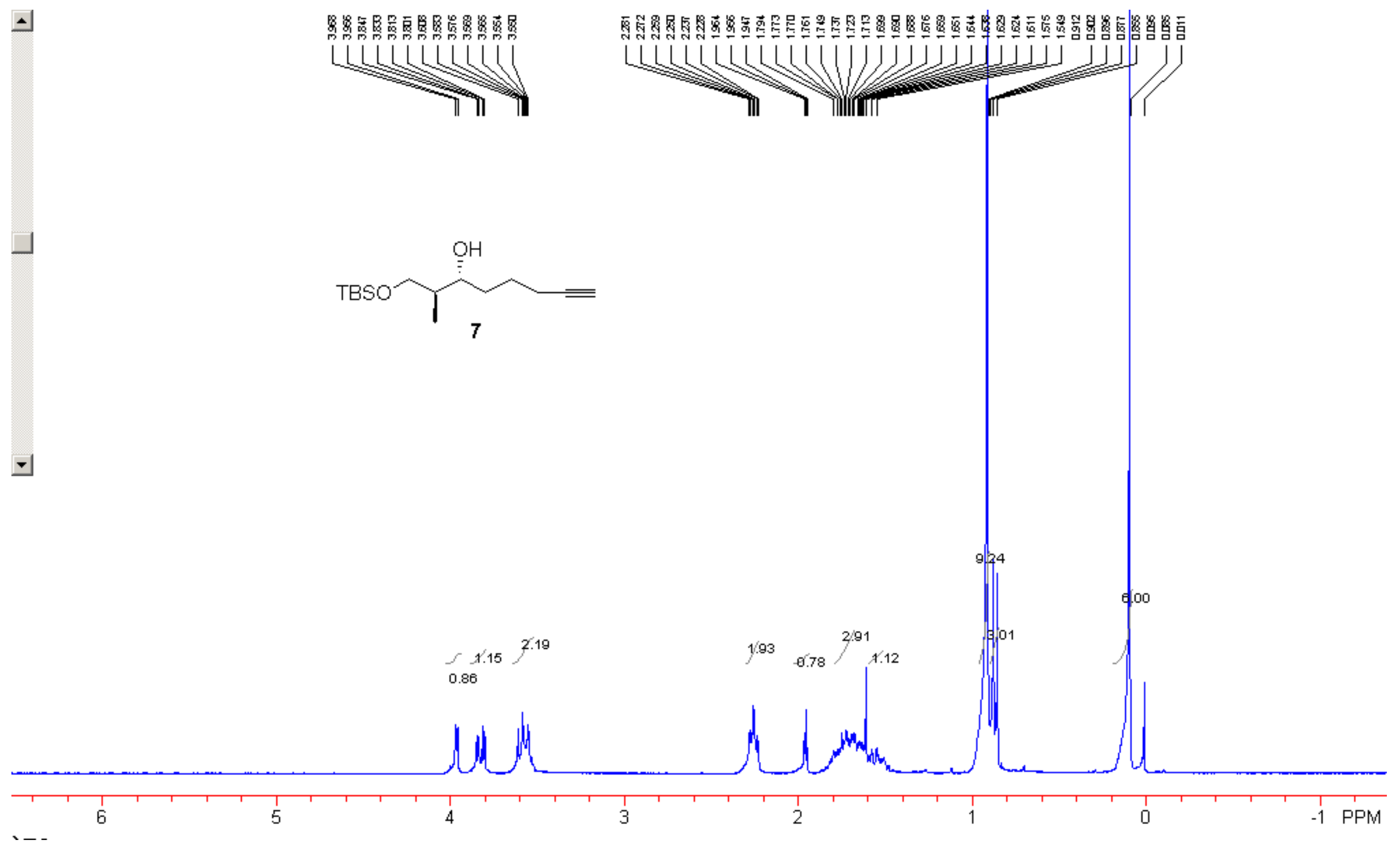



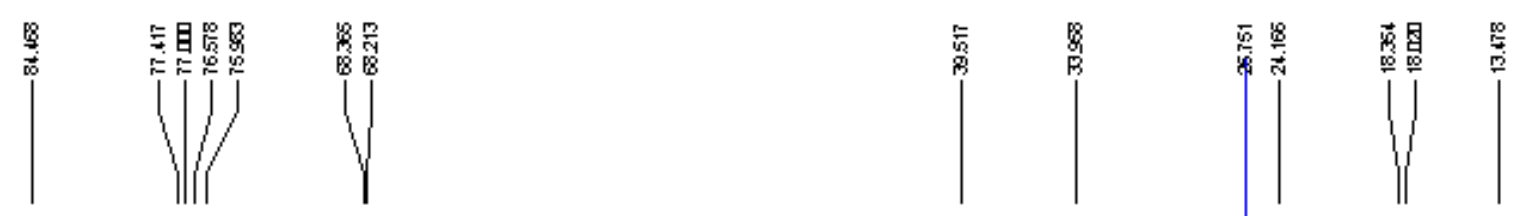

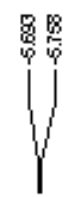

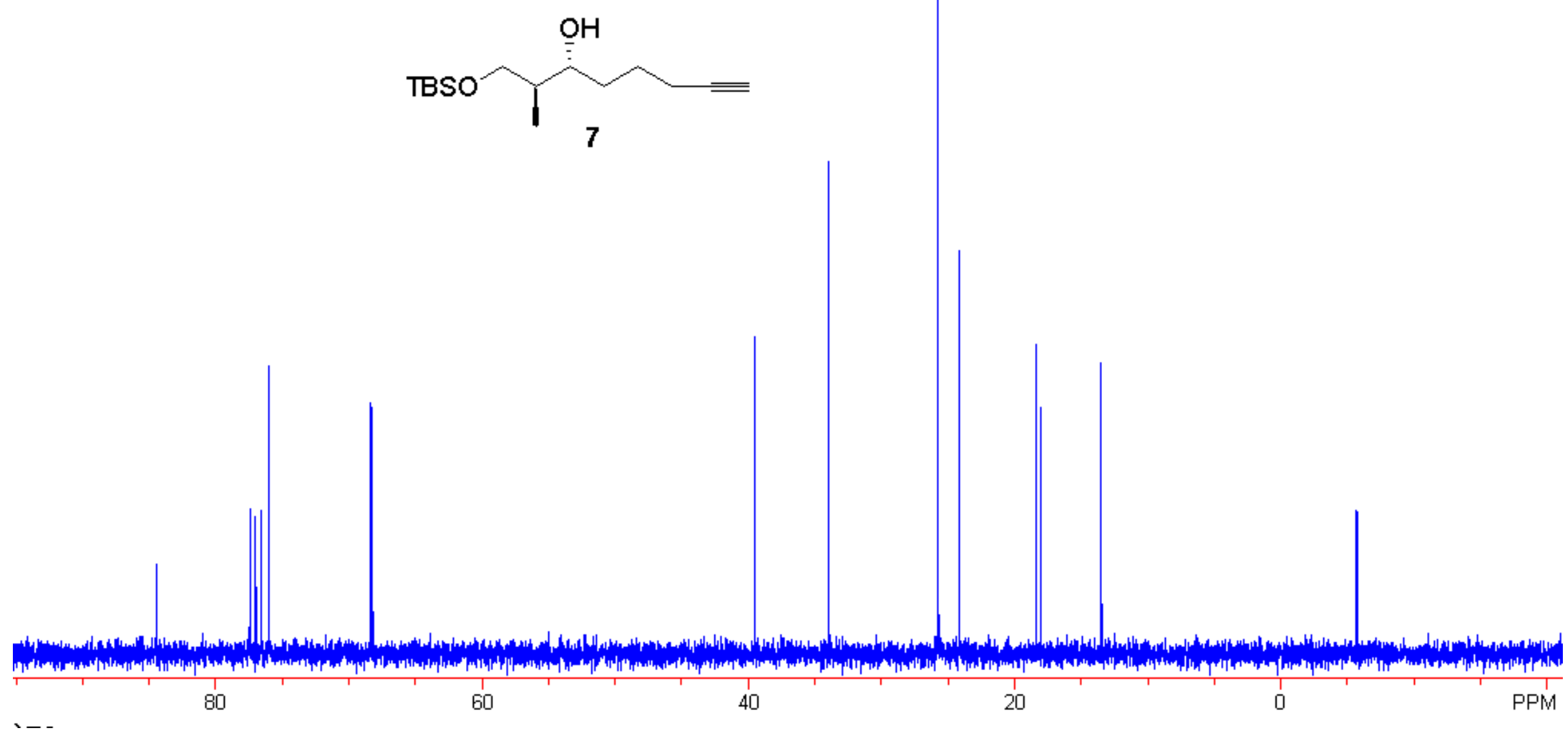




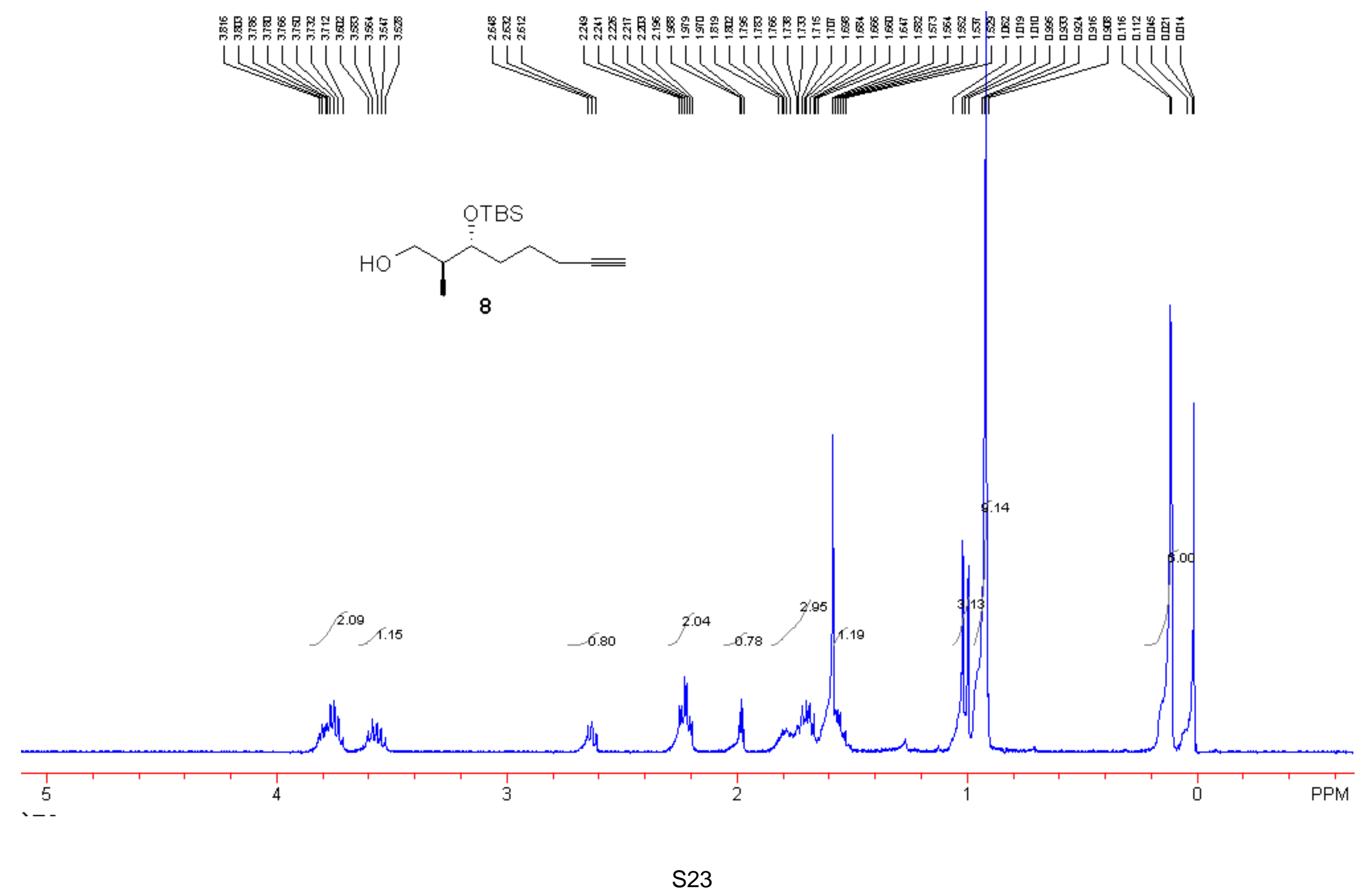



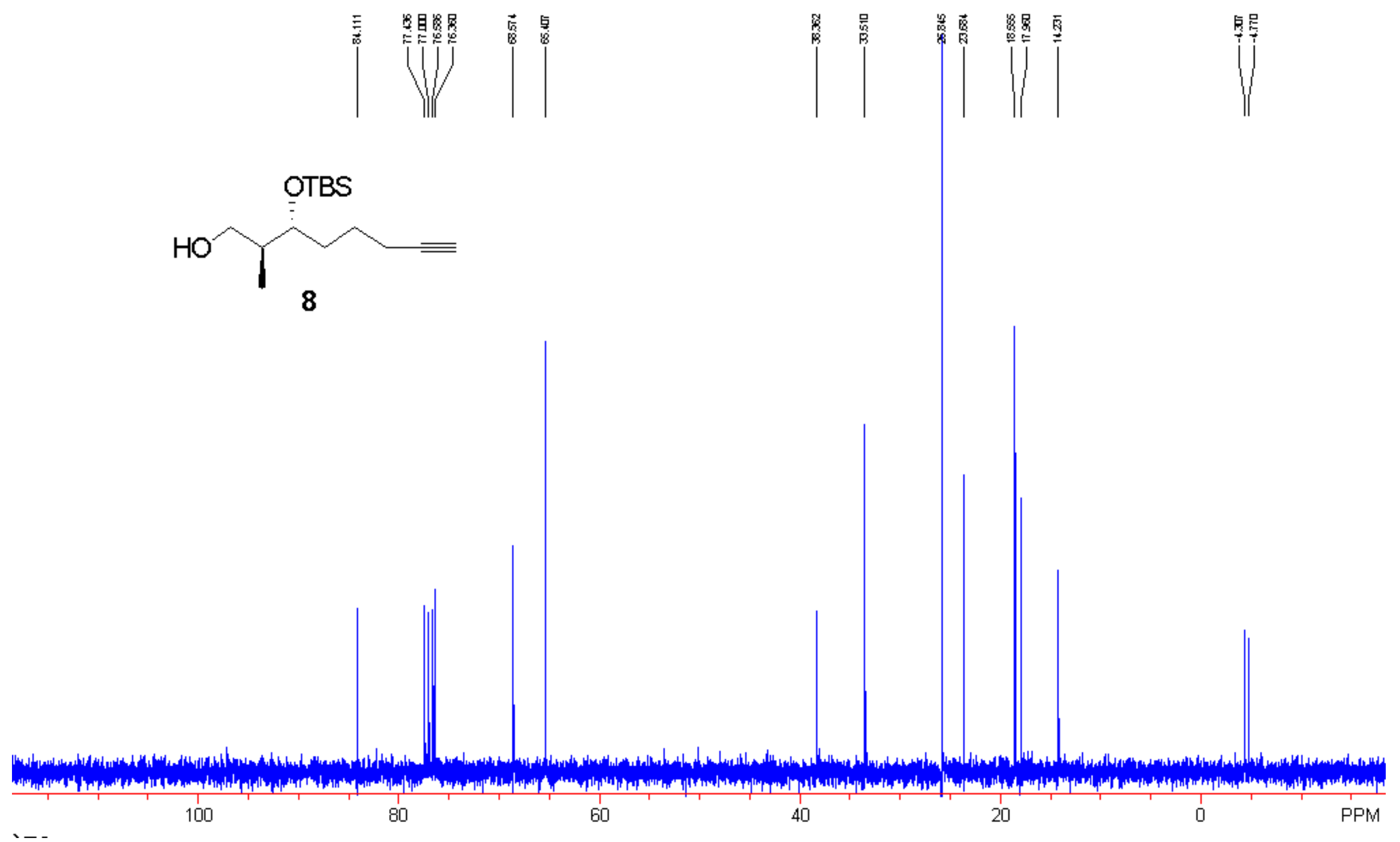

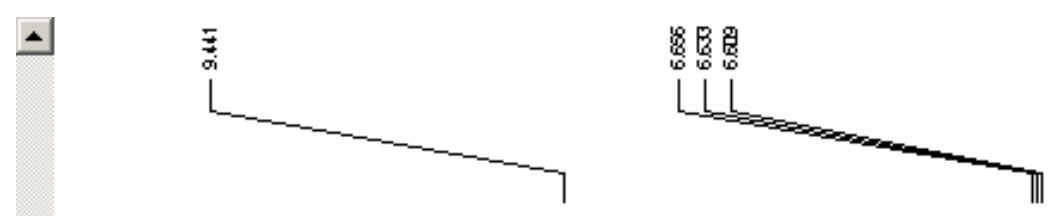

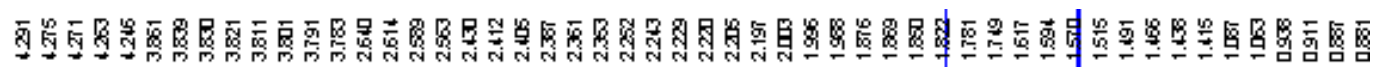

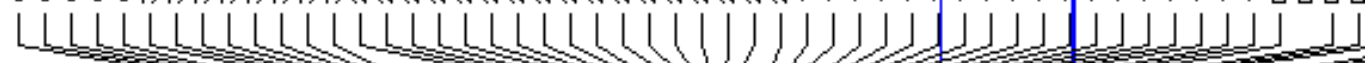

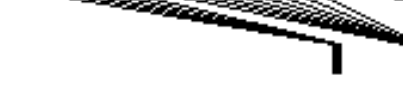

$\square$

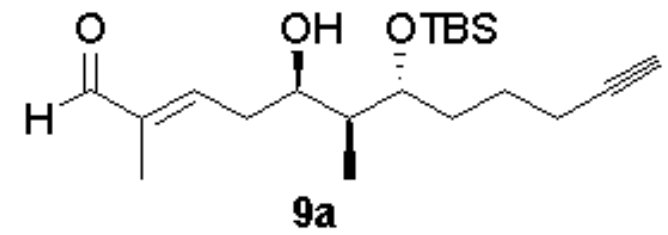

$\nabla$

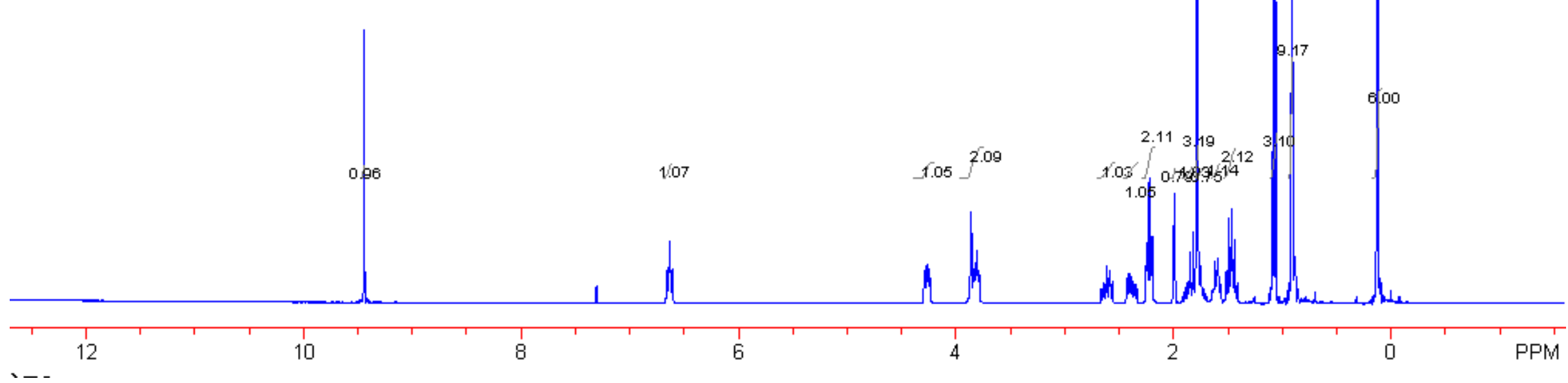



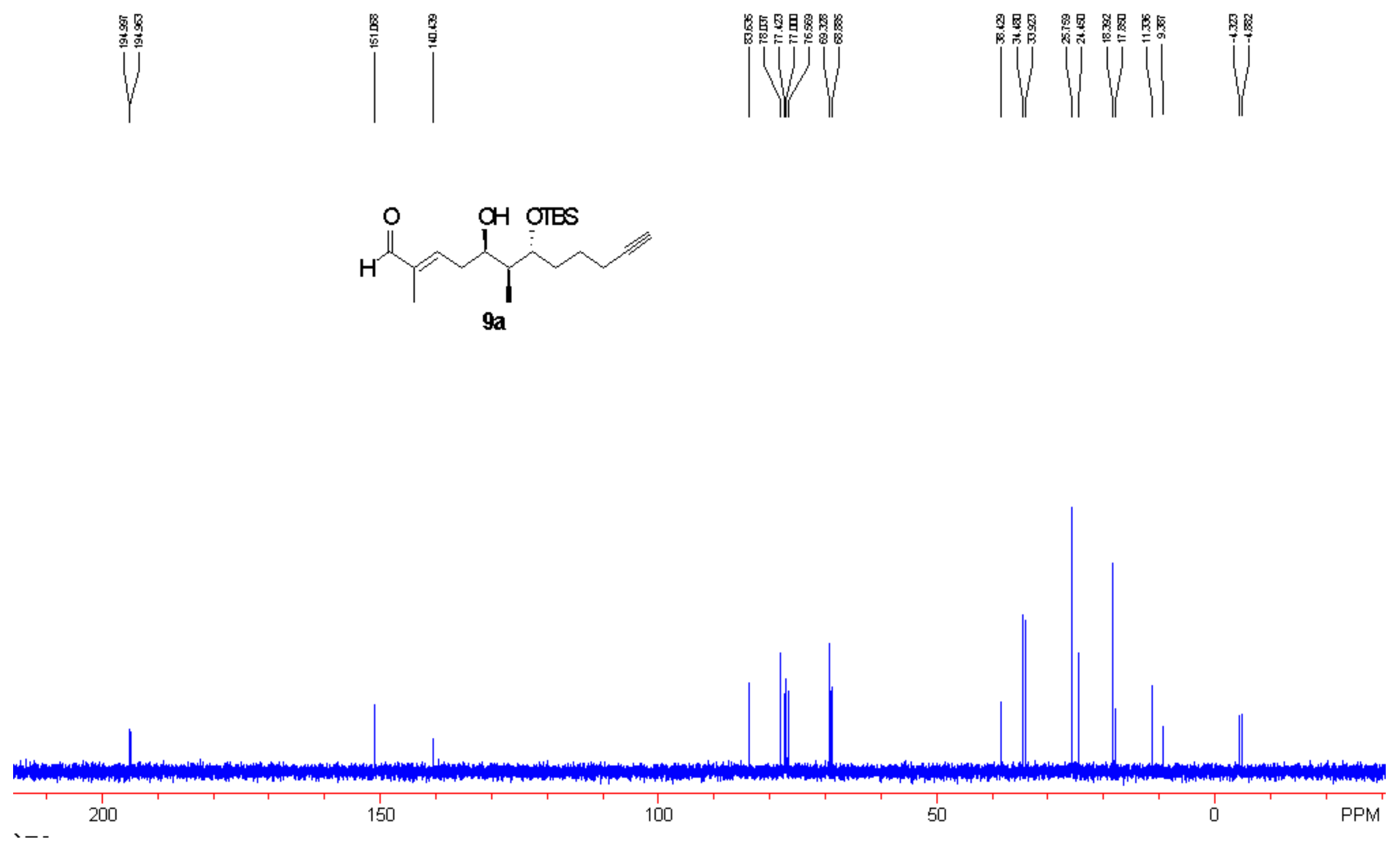


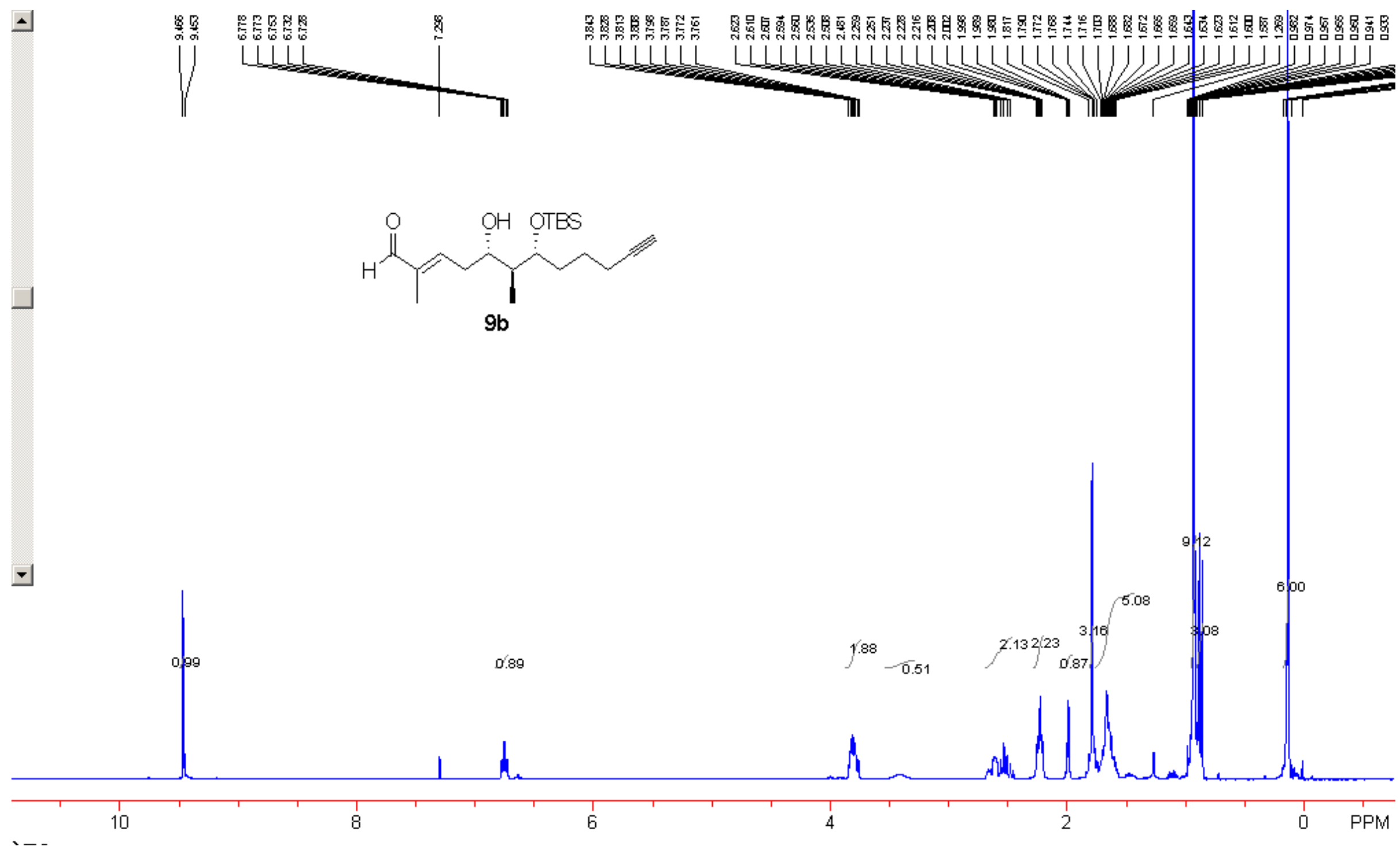


<smiles>C#CCCC[C@@H]([OH2+])[C@@H](C)[C@@H](O)C/C=C(\C)C=O</smiles>

$9 b$

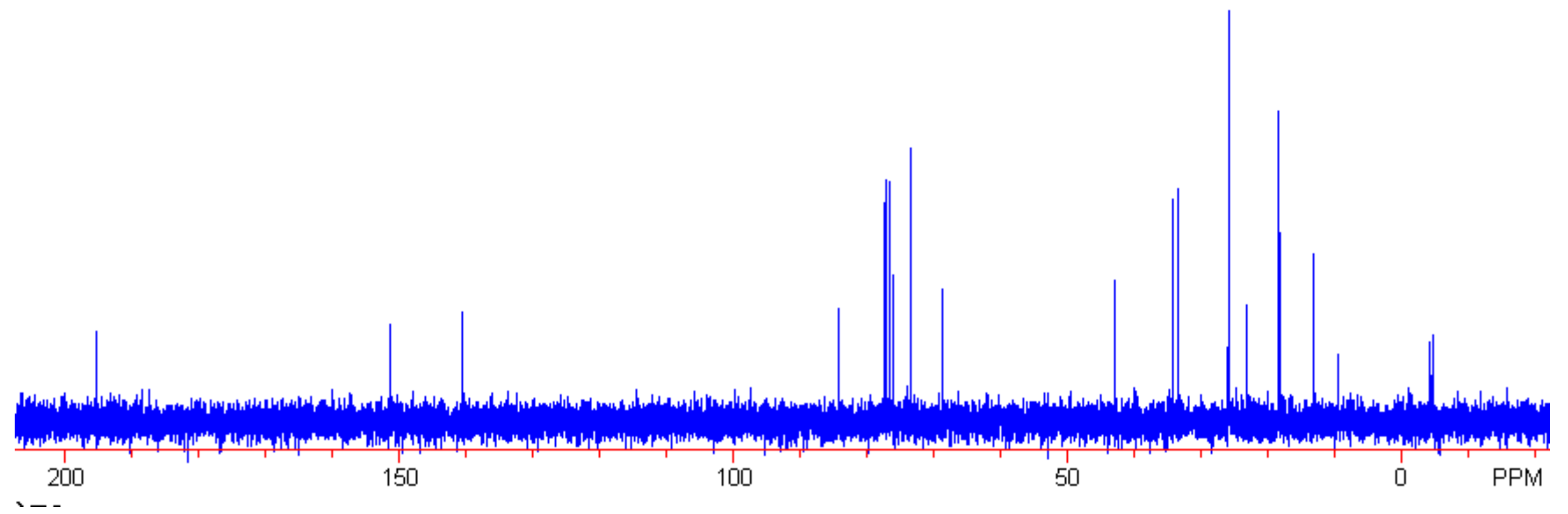




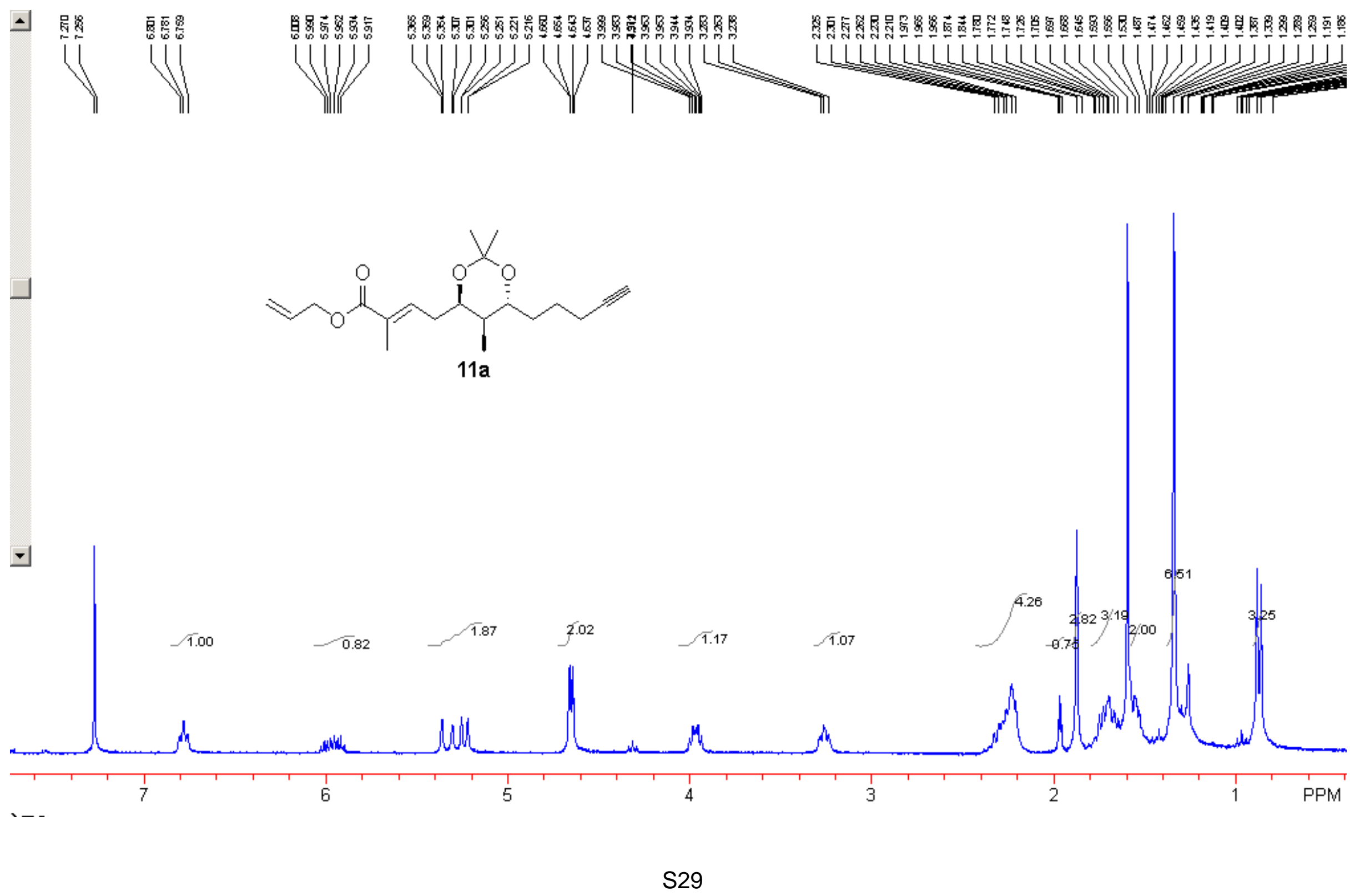



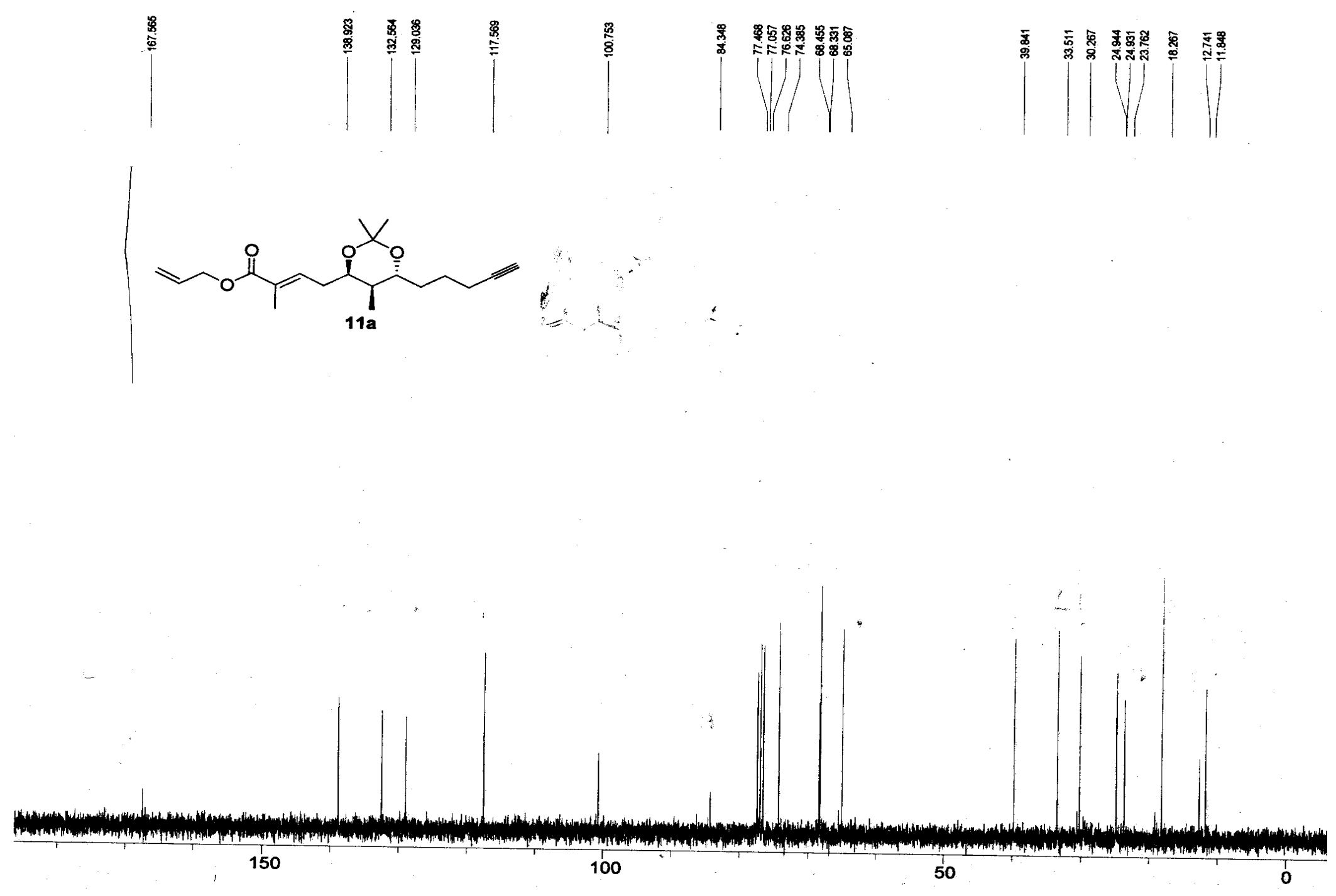


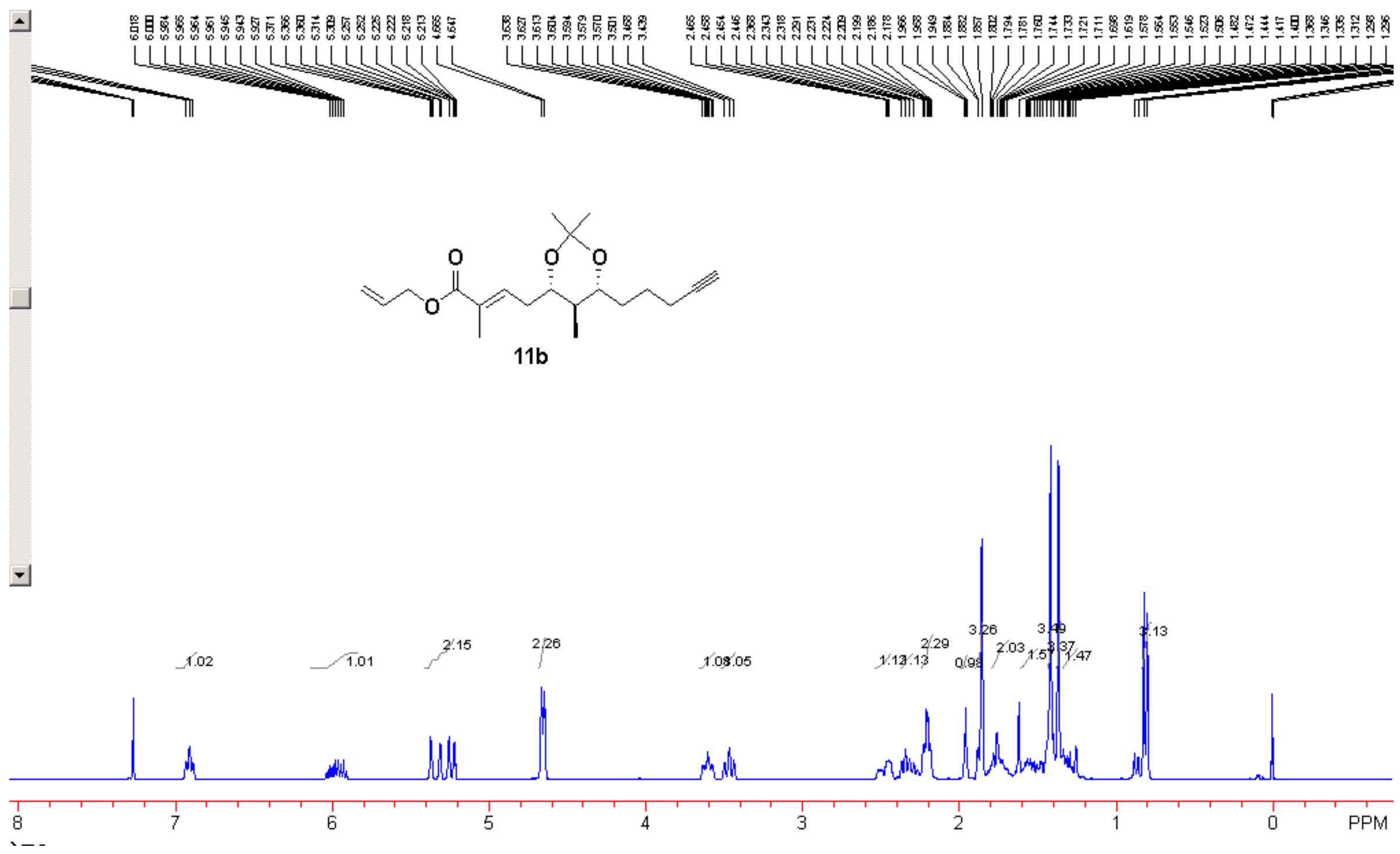



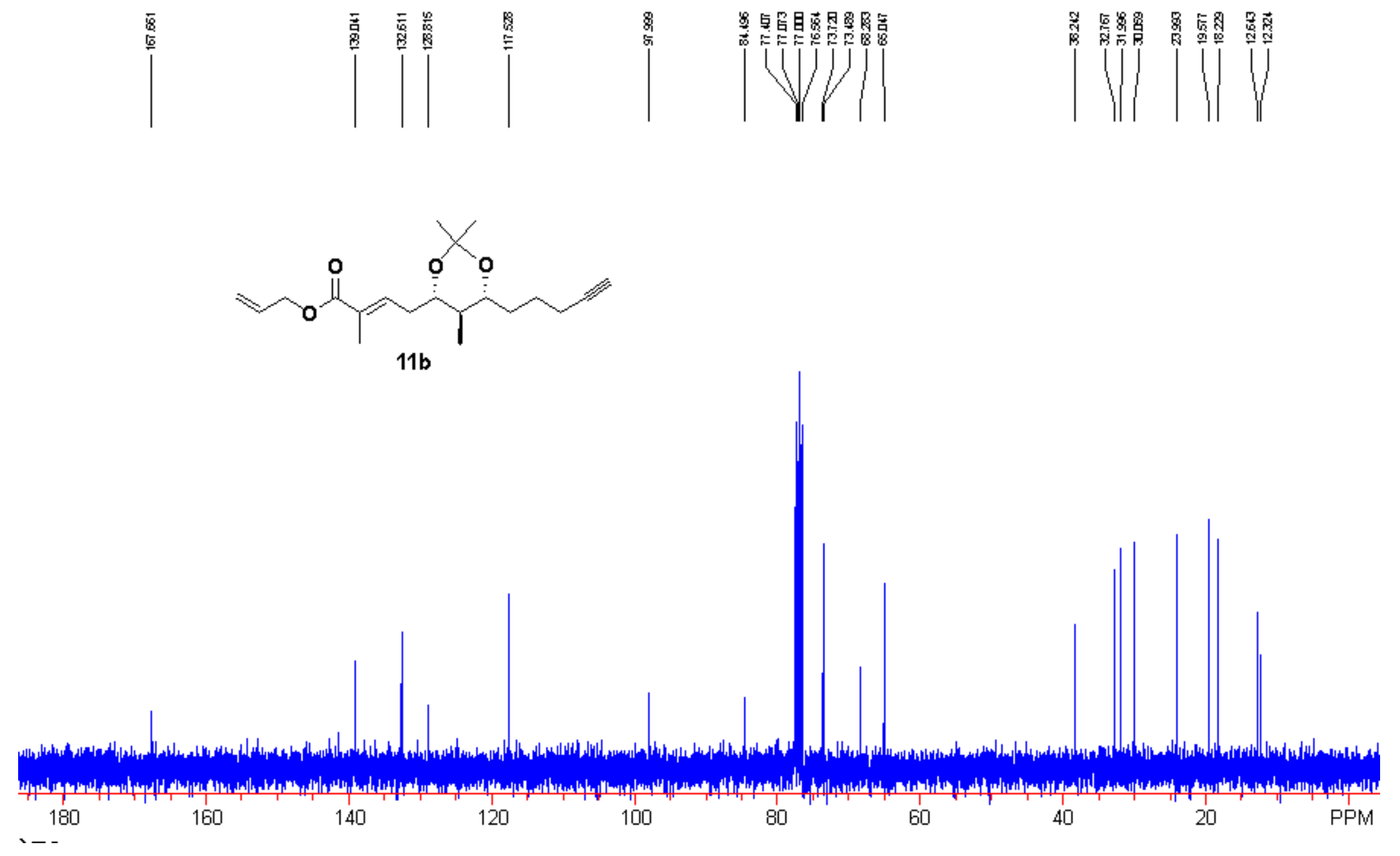


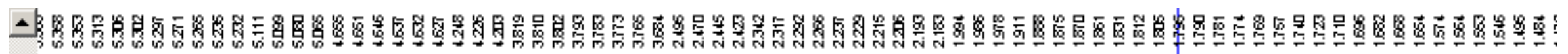

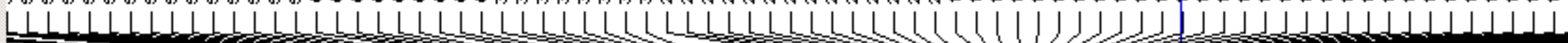

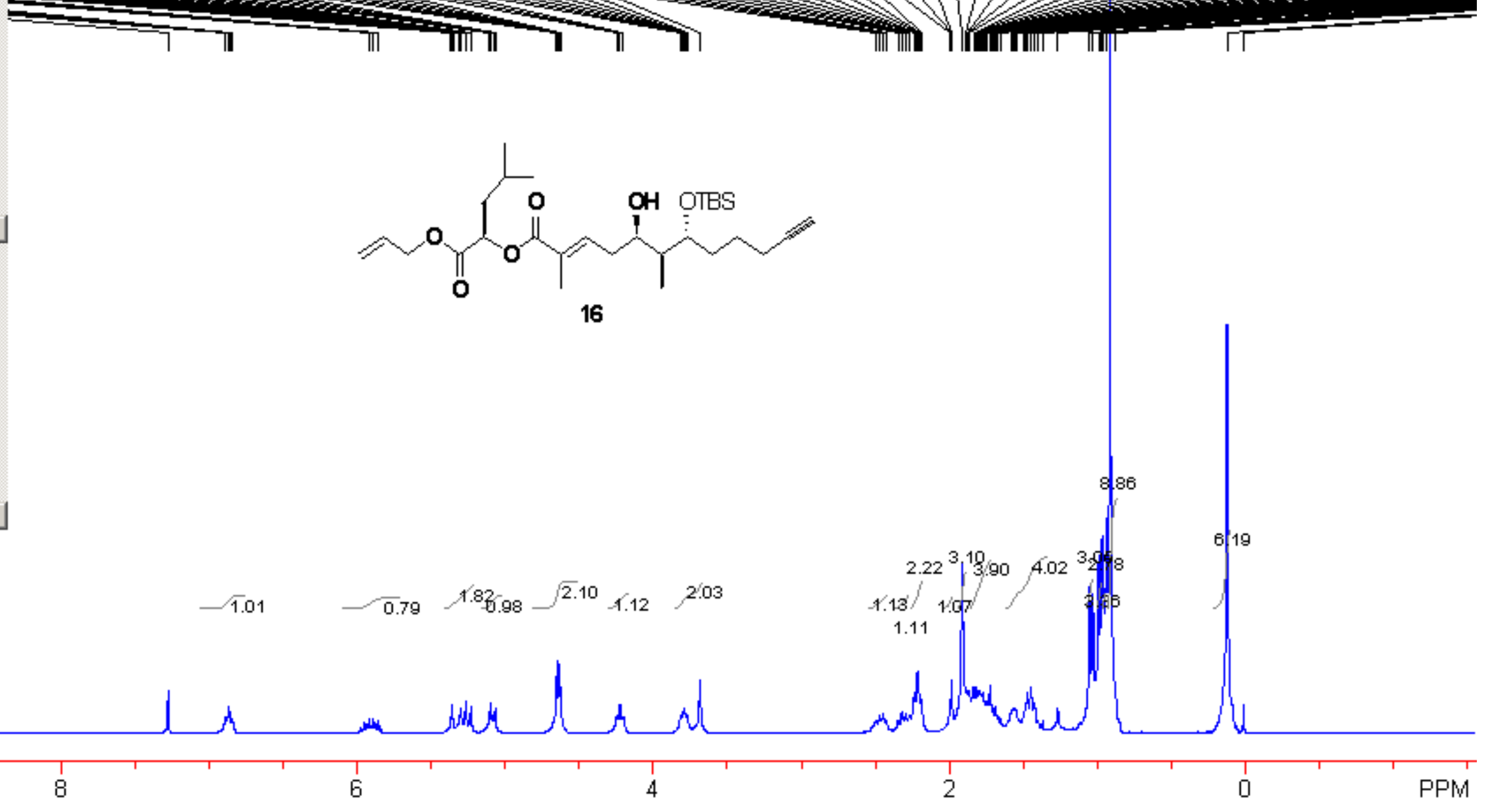



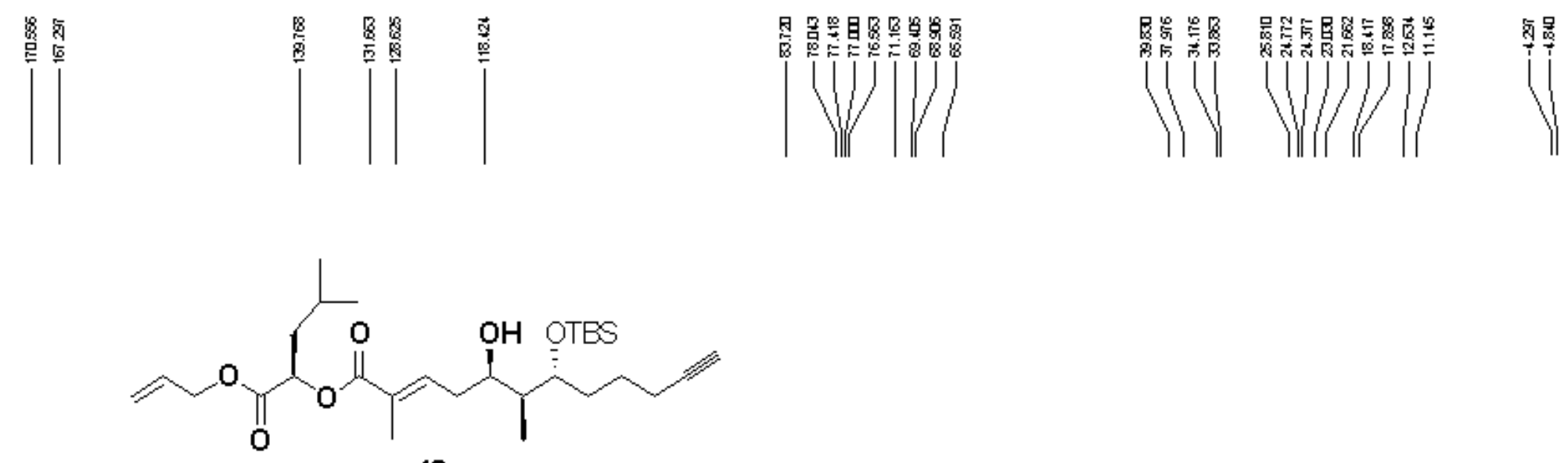

16

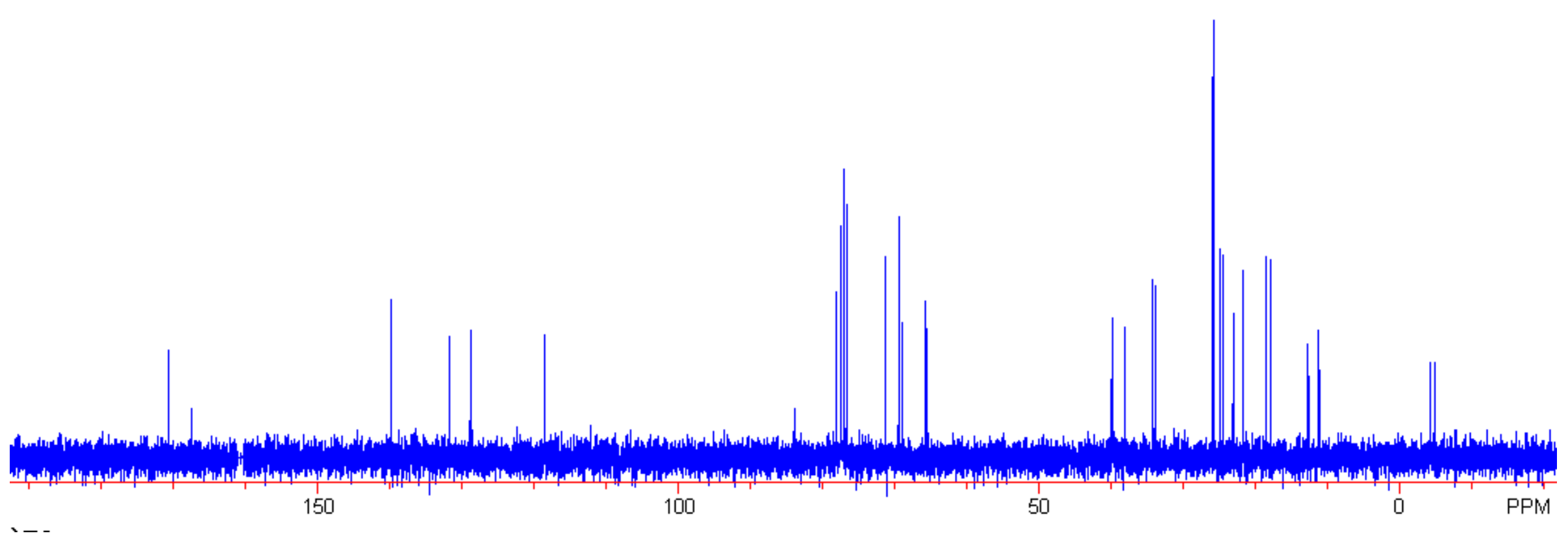




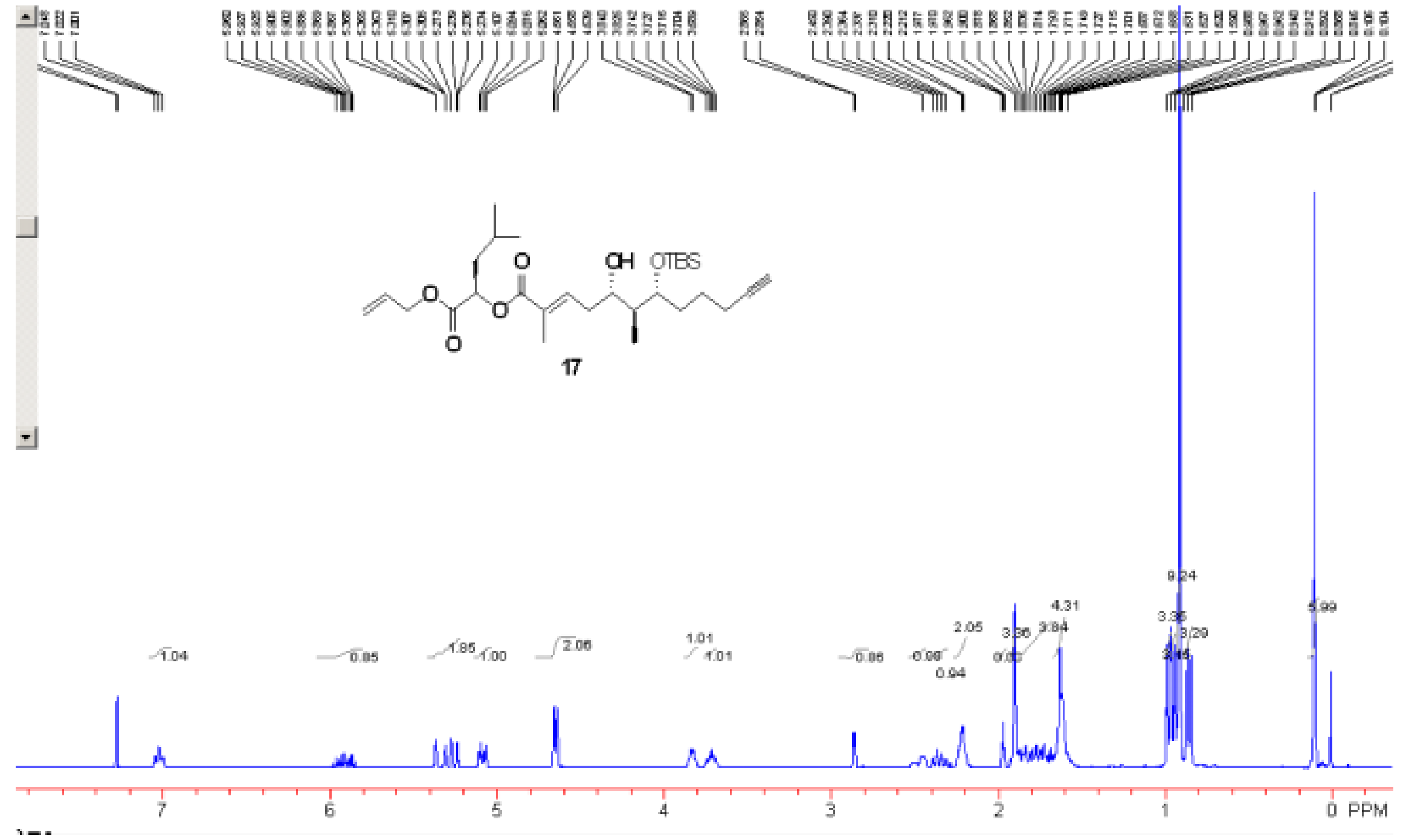



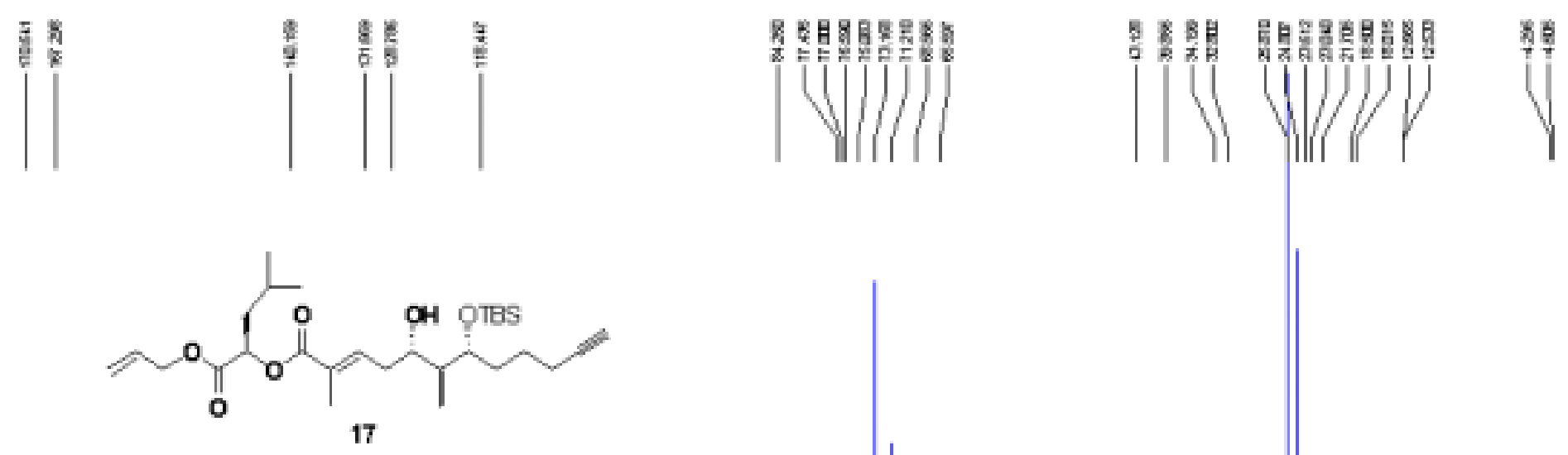

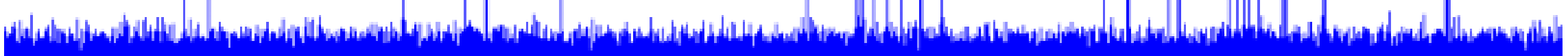

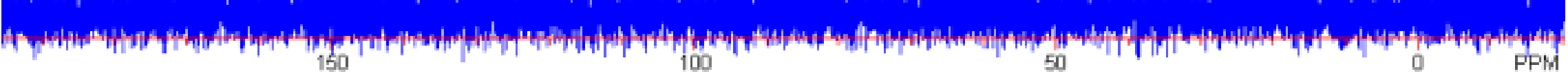



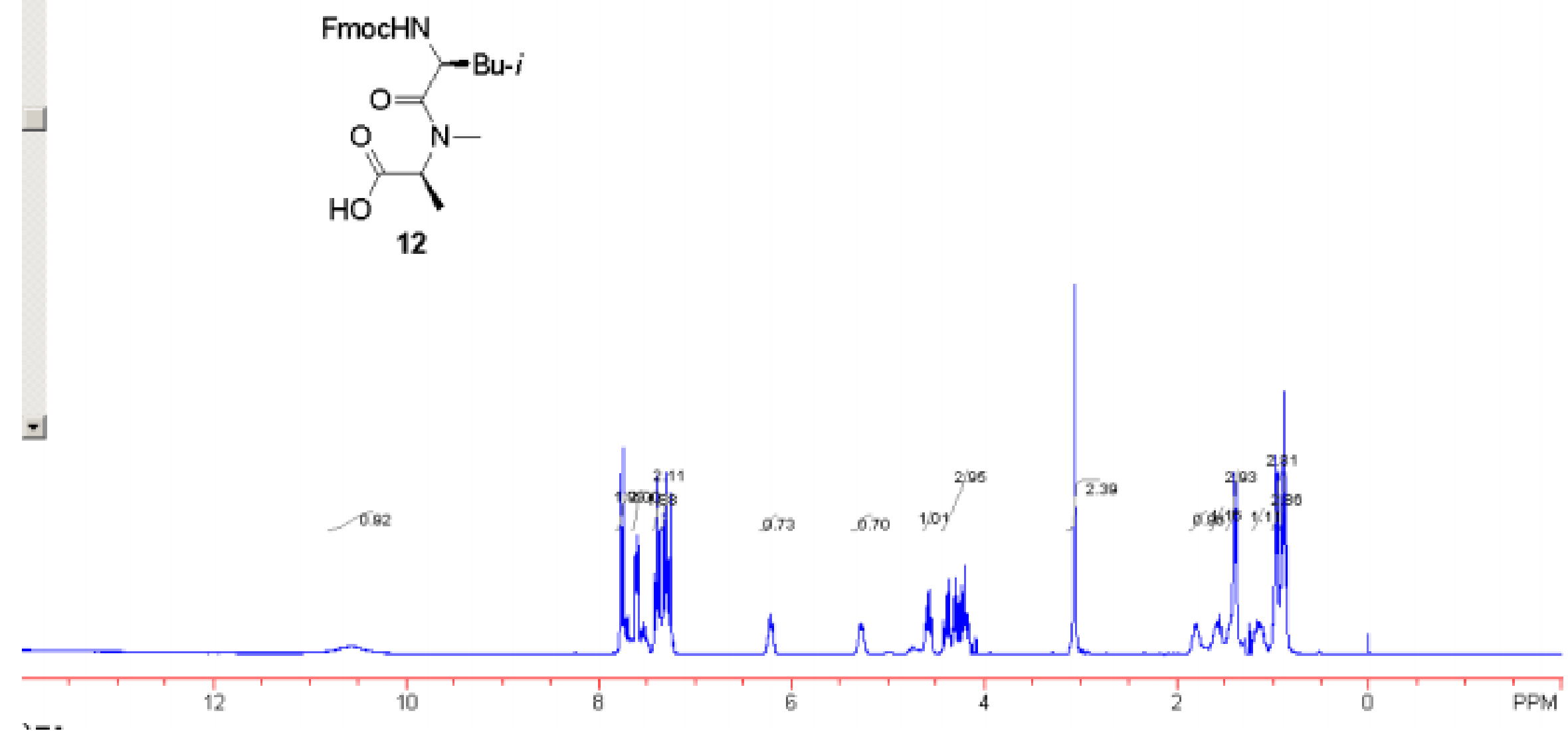


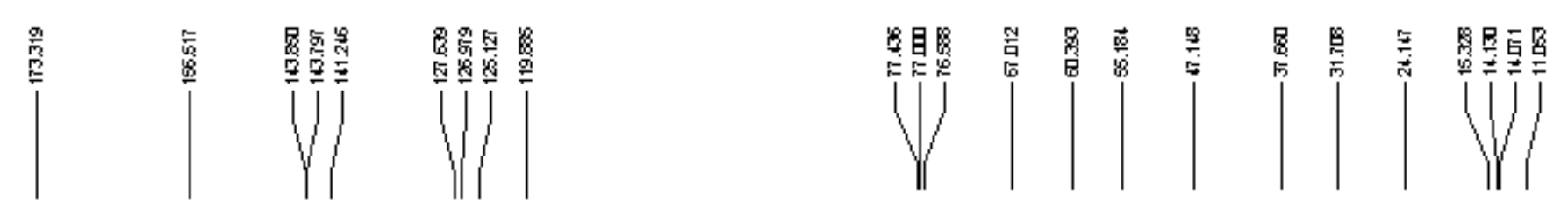

$$
\text { (mocHN }
$$

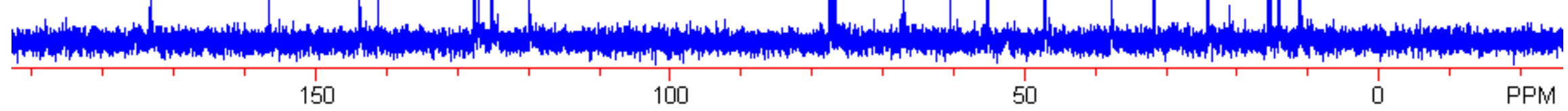




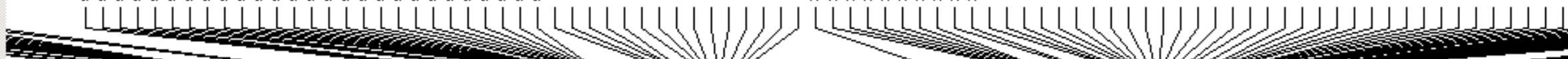

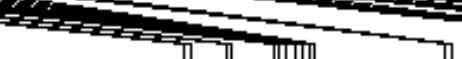
Tा = Tा TाII
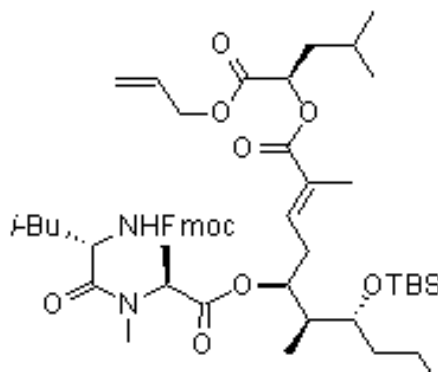

18

$-$

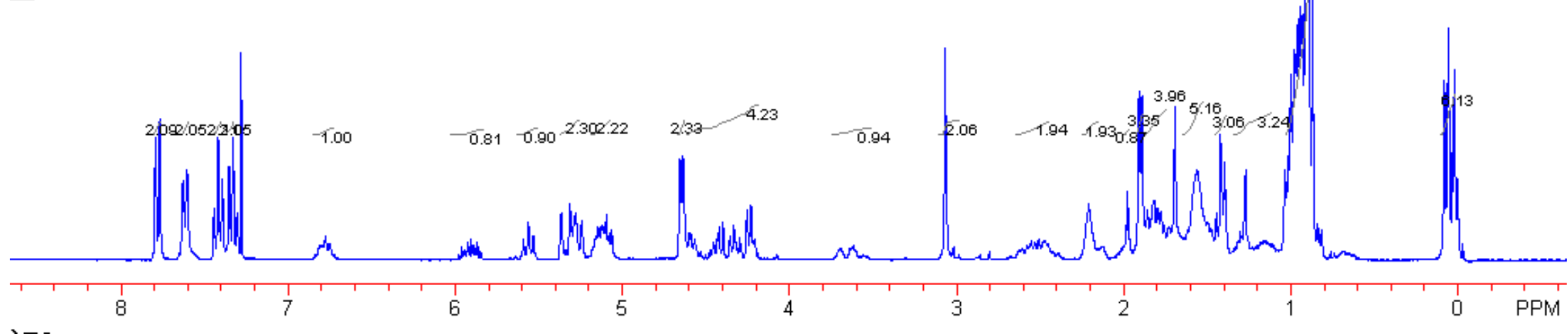




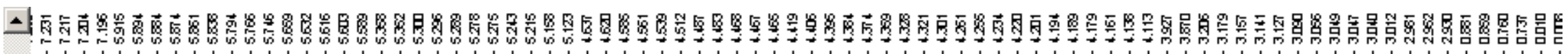

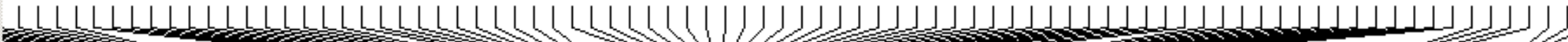

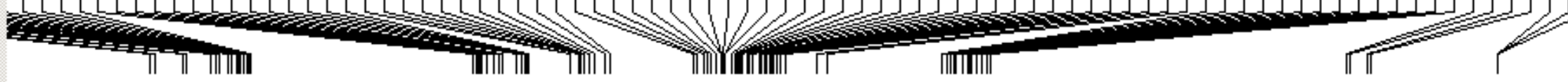

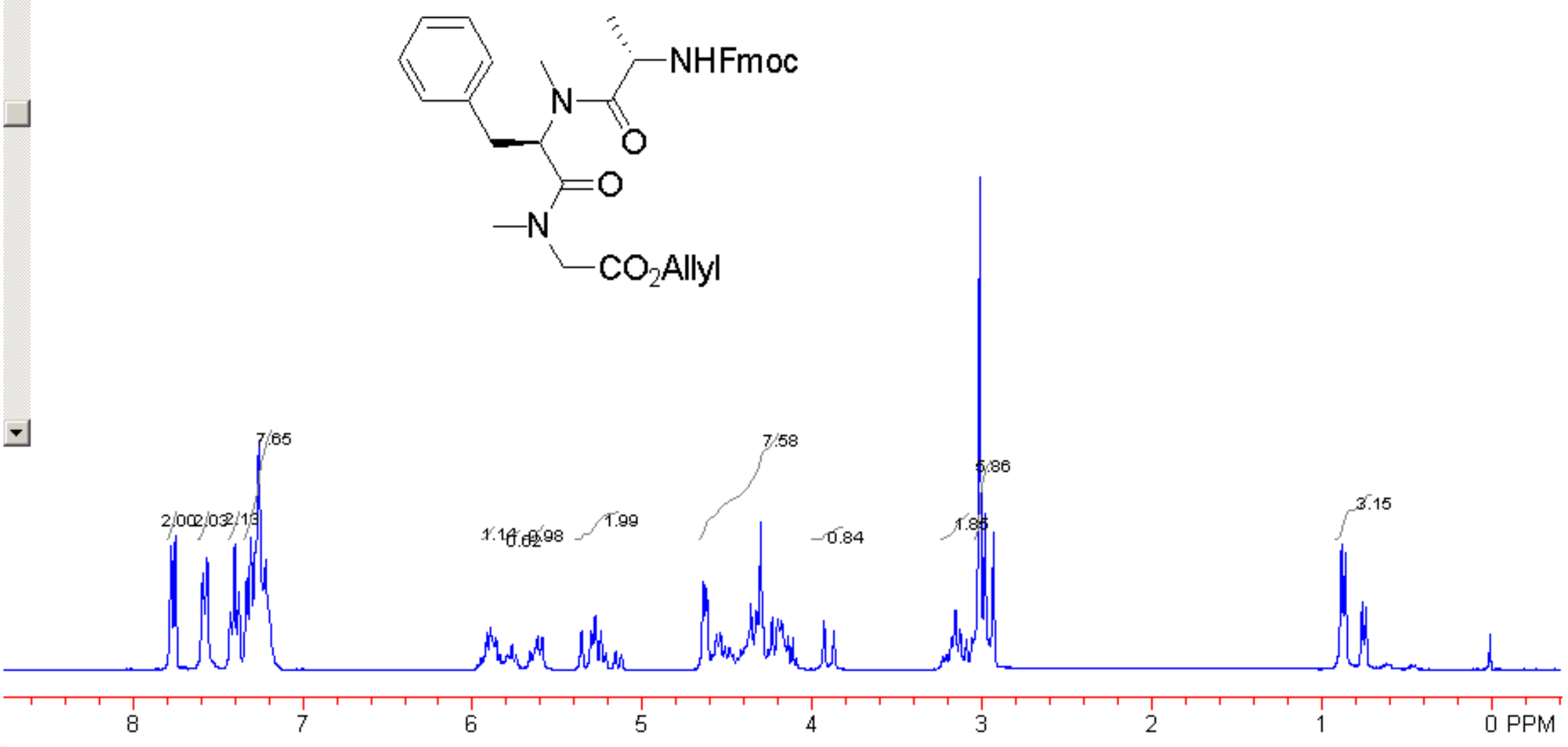



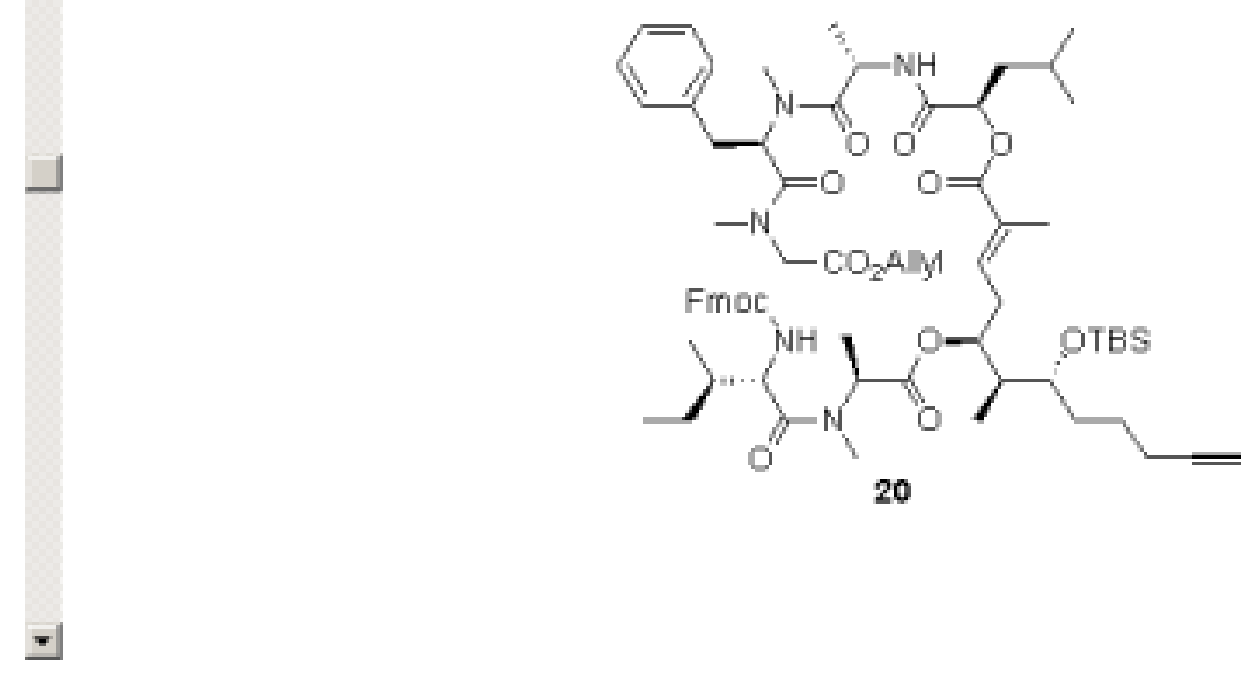

.

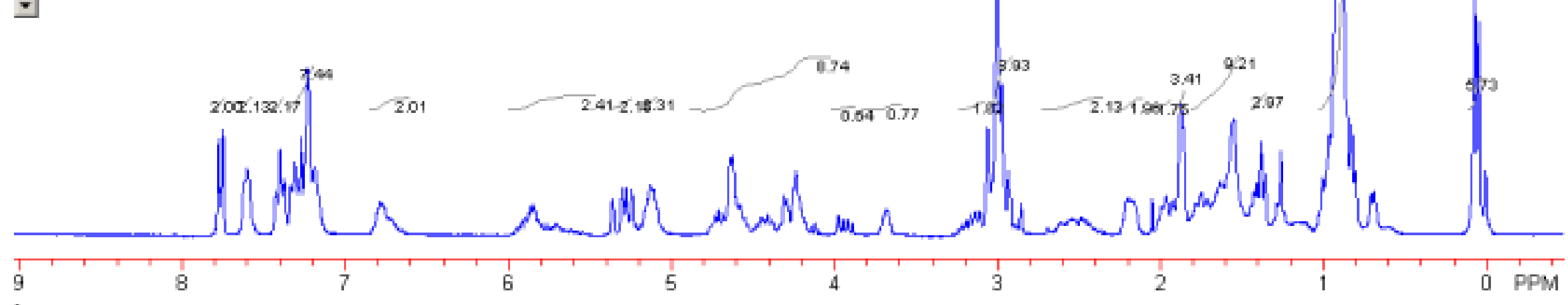




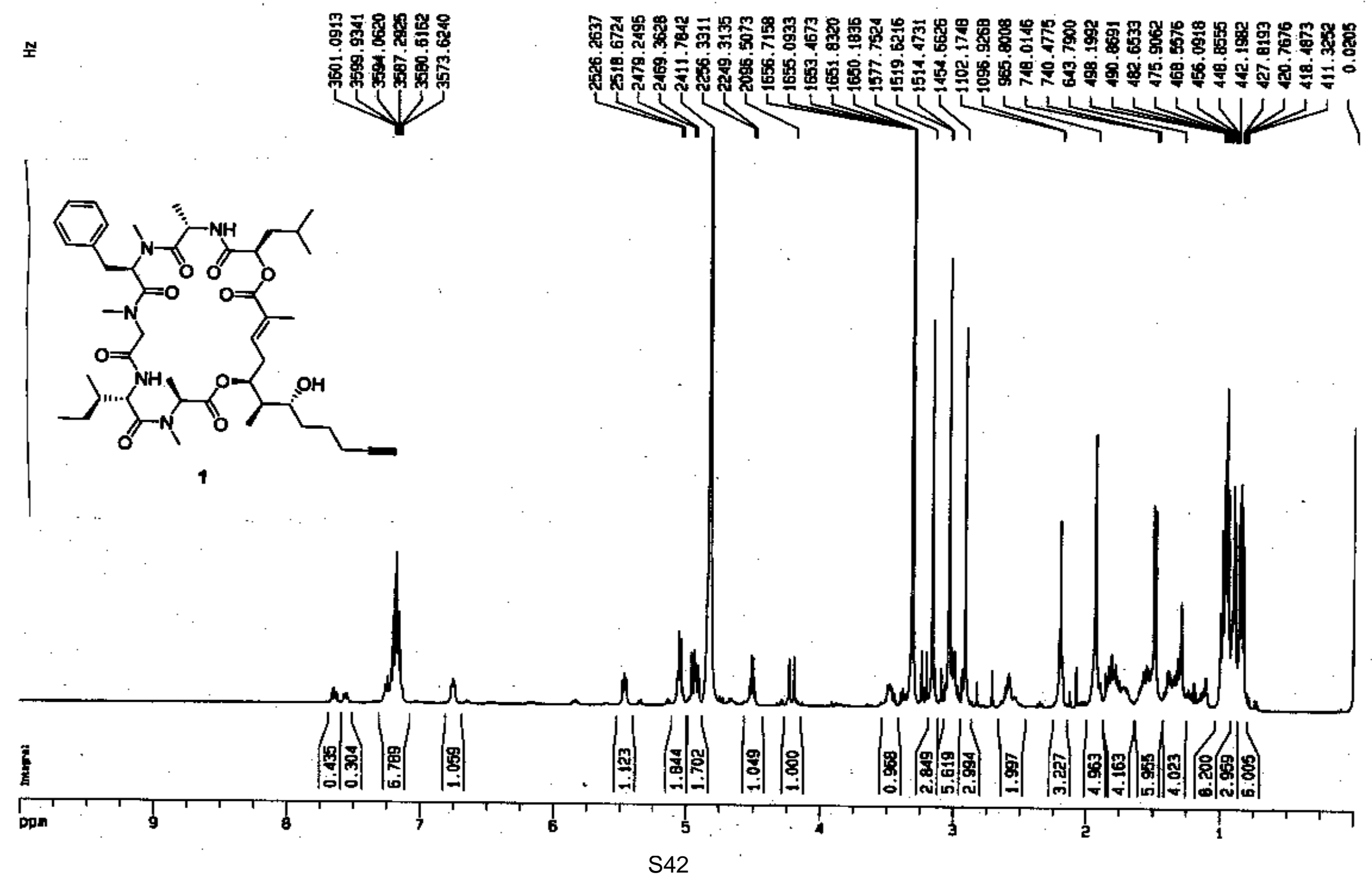

